\title{
Does the Variability of Other Comprehensive Income (OCI) Play a Role in the Determination of Cost of Debt, Capital Structure and Credit Ratings?
}

\begin{abstract}
In this paper, we focus on the usefulness of other comprehensive income (OCI) to debt investors. We conceptualize OCI's usefulness to be its risk relevance. We hypothesize that credit risk is associated with OCI volatility and so we contribute to the debate whether this volatility is viewed by creditors as capturing useful information about debt risk or just "noise." Specifically, we consider whether OCI's volatility that is linked to accounting standards in the recent two decades is associated with cost of debt, non-price terms of debt contracting (i.e. covenants, security), capital and maturity structure, and credit ratings. We construct three samples to conduct our tests: (1) a new loan sample from Dealscan and (2) a comprehensive sample from COMPUSTAT and (3) credit ratings sample. We find strong evidence that higher volatility of $\mathrm{OCI}$ is associated with a higher cost of debt, higher likelihood of collateral requirement, and stronger credit rationing (lower use of debt). We also find statistically significant but economically weak evidence that OCI volatility is related to shorter debt maturity and lower credit ratings. Overall, our evidence suggests that OCI volatility provides useful information to credit markets and shapes debt contracting and the firm's capital structure accordingly.
\end{abstract}




\section{Does the Variability of Other Comprehensive Income (OCI) Play a Role in the Determination of Cost of Debt, Capital Structure and Credit Ratings?}

\section{Introduction}

In this study, we investigate whether the volatility of other comprehensive income (OCI) is related to credit risk. Our concentration on OCI's link to credit risk supplies evidence for reconciling the debate about benefits of OCI information to lenders. This debate has recently resurfaced with the FASB's and IASB's continuing projects on the statement of comprehensive income. Past researchers (i.e., Dhaliwal, Subramanyam, Trezevant 1999) and practitioners ${ }^{1}$ (see Yen, Hirst and Hopkins 2007 for a summary of practitioner comments) support the view that the accounting adjustments contained in OCI have caused the volatility of OCI to be viewed as "noise" rather than decision-useful for investors. Other research (Chambers, Linsmeier, Shakespeare, Sougiannis 2007; Black, 2016, Jones and Smith, 2011 and Holthausen and Watts, 2001) provides theoretical support for OCI's decision-usefulness. ${ }^{2}$ However, the empirical support contained in this stream of research focuses on equity investors (Chambers, Linsmeier, Shakespeare, Sougiannis 2007 and Black, 2016) but not on creditors.

Due to asymmetric payoff structure between debt and equity claims, creditors' risk concerns naturally differ from those of equity holders because creditors focus on the safe repayment of principal and interest. Therefore, even if firm policies increase the probability of future OCIrelated gains as well as future losses equally, risk deteriorates to creditors due to asymmetric payoff structure. We posit that OCI volatility contains useful information about credit risk. For example, high OCI volatility may arise due to large current-currency adjustments that indicate not only the exchange rate exposure of the firm but also the size of the firm's foreign operations. OCI volatility

\footnotetext{
${ }^{1}$ See Richard J. Schlueter's letter for Emerson Electric found at FASB.org comment letter, File Reference No. 1790-100, Comprehensive Income.

${ }^{2}$ Skinner (2011) provides theoretical support of OCI's usefulness to debt holders but no empirical support.
} 
may also be high due to uncertainty of the funding status of the firm's pension plan. Since the firm assumes the burden of unfunded portion of pension plan liabilities, creditors should be naturally concerned about the presence of another claim against the firm's assets. Finally, OCI volatility may also be related to investments in marketable securities creating fair value adjustments to OCI. Facing these potential issues, we expect that creditors to respond accordingly to protect the value of their claims by imposing higher cost of debt, more restrictive borrowing terms and/or by rationing credit.

The natural conflict between creditors and shareholders due to asymmetric payoff is further exacerbated by asset substitution. Asset substitution occurs when managers borrow money for the firm with the promise that the proceeds will be used for investments of a certain level of riskiness and then later use the funds for investments with greater riskiness such as larger upside returns but also larger downside losses. This type of investment may benefit equity holders but harm creditors. We suggest the projects that the manager might be considering give rise to adjustments to OCI, such as expansion of foreign operations, additional investments in marketable securities related to fair value adjustments to OCI or motivating the labor force leading to an expansion of the firm's defined benefit plan with the need for more pension assets. ${ }^{3}$ Since the Federal Reserve System reports $\$ 780$ billion in net debt security issuances during the past decade and only $\$ 2$ billion for equities (Graham, Li and Qiu, 2008), addressing the lack of research investigating the risk relevance of OCI for debt investors represents a significant opportunity to improve the understanding of OCI's value in promoting the functioning of capital markets. ${ }^{4}$

\footnotetext{
${ }^{3}$ Many of effects of these investments on OCI volatility are argued to be out of the control of management. These include changes in stock prices, affecting marketable securities and the pension asset, or changes in currency rates affecting the current-currency adjustment. However the original choice to enter into these investments represents a management decision and so we suggest may be related to asset substitution. In addition, we suggest that the increase riskiness related to these effects as measured by increased OCI volatility may concern creditors.

${ }^{4}$ In an effort to keep the reader focused, we touch briefly on what our paper does not do. Our paper does not make arguments on whether volatility of OCI affects the accounting quality of a firm or whether OCI numbers should be used in debt contacts. Instead, we test whether the volatility of OCI
} 
We motivate the importance of our analyses by three descriptive characteristics of OCI volatility from our analysis that should be concerning to the firm's creditors. First, we find that OCI volatility (STD_CHG_AOCI/A) averages 1.2 percent, which is economically significant as it amounts to one-fifth of average ROA volatility (6.2 percent). Second, OCI volatility is uncorrelated to ROA volatility suggesting that OCI might contain useful credit risk information that is not captured by the traditional ROA volatility. Third, we show that OCI is positively correlated to market portfolio returns, suggesting that OCI volatility is not eliminated via diversification and carries systematic risk. To reinforce our motivation, we provide an illustrative theoretical model in Appendix 1. The model shows that when OCI has zero expected value but has positive correlation to market returns, even risk-neutral creditors will lower the value of their claims as OCI volatility increases. We also discuss that risk-aversion, and agency costs further exacerbate creditors' concerns. Whether or not the capital markets provide support for our theoretical predictions about the importance of OCI volatility to creditors is the question that we empirically investigate in our research.

We test risk relevance of $\mathrm{OCI}$ from the perspective of debtholder by starting with a private loan sample and extend our analysis to COMPUSTAT samples. First, we use a private loan sample to test whether the debt markets perceive the volatility of OCI to contain risk information. Our focus on private loans follows from past research showing that firms' loans from private lenders are harder to evaluate than firms' publicly traded bonds because they have higher credit risk (Diamond 1991; Rajan 1992; Denis and Mihov 2003). We consider the association between the volatility of OCI and each of the following: (1) the cost of private loans, (2) incidence of loan covenants, (3) collateral requirement and (4) the maturity structure of loans. Second, we use a broadly based debt maturity sample taken from COMPUSTAT. We investigate the association between the volatility of OCI and

indicates riskiness of a firm in the eyes of creditors that may not be captured by other accounting numbers. 
the following: (1) the maturity structure of debt and (2) leverage. Finally, we investigate the link between credit rating and the volatility of OCI based on a COMPUSTAT sample. Our key variable is the volatility of $\mathrm{OCI}\left(S T D_{-} C H G_{-} A O C I / A\right)$. We measure $S T D_{-} C H G_{-} A O C I / A$ as standard deviation of annual change in accumulated other comprehensive income scaled by total assets over the past five years. This straightforward measurement of volatility of $\mathrm{OCI}$ is consistent with the methodology used to measure traditional ROA volatility, commonly used in the literature to proxy for riskiness of earnings. We empirically examine whether credit spreads increase, covenants become more restrictive, debt usage declines and debt maturity shortens when OCI volatility increases. We also test whether credit ratings deteriorate when OCI volatility is higher. We find economically and statistically significant evidence that, as OCI volatility increases, the cost of debt increases, there is a higher likelihood of collateral requirement and the use of debt decreases. In addition, we find statistically significant but economically weak evidence that higher OCI volatility results in shorter maturity and lower credit ratings. Overall, our evidence lends support to the view that OCI volatility provides useful information about credit quality to debt holders.

Our study provides important findings that contribute to the literature investigating the decision-usefulness of volatility of OCI. The central debate regarding OCI's information content to debt holders in this literature focuses on whether OCI volatility is simply "noise" or provides decision-useful information to debt markets. By showing that higher OCI volatility is associated with economically and statistically significant higher cost of debt, higher likelihood of collateral requirement and lower use of debt we contribute support for the decision-usefulness of OCI volatility information to debt holders. Our findings imply that OCI volatility provides additional useful information regarding credit risk that is not captured by other information proxies. Our investigation contributes support to the continued interest by the FASB and IASB through their policy deliberations in providing guidance associated with OCI reporting that focuses on the needs of creditors (Huang, Lin and Raghunandan 2015). 
Our study also expands the literature on the role of accounting standards in debt contracting. Past literature shows that accounting information plays an important role in shaping debt contracts (Armstrong, Guay and Weber, 2010; Ball, Bushman, and Vasvari, 2008). To the best of our knowledge, our paper is the first to document statistically and economically significant effects of OCI volatility on the debt financing environment.

The rest of the paper is organized as follows. Section 2 develops hypotheses. Section 3 discuss sample construction and outlines the research design. Section 4 presents the results. Section 5 concludes the study.

\section{Hypothesis development}

Past accounting research supports our argument that the OCI volatility may be perceived as an indicator of company risk by investors. Yen, Hopkins, and Hirst (2007) analyze the comprehensiveincome exposure draft comment letters. They conclude that banking organizations opposed the Financial Accounting Standards Board's (FASB) proposal for comprehensive-income because they claimed that it would trigger "excessive" volatility in comprehensive income, and lead investors supposedly to "overstate their risk assessments." Hodder, Hopkins and Wahlen (2006) then provide evidence refuting the claim of potential "overstated risk assessments." They show the volatility of comprehensive income to be more risk relevant compared to the volatility of net income for a sample of U.S. banks for the sample period from 1996 to $2004 .{ }^{5}$ This past research focuses on the usefulness of OCI volatility information only to equity investors. However, there are strong theoretical reasons to suppose that the needs of creditors may differ from equity investors. We fill a gap in the literature by extending the evaluation of the usefulness of OCI information to creditors. Specifically, we

\footnotetext{
${ }^{5}$ Hodder, Hopkins and Wahlen (2006) report that OCI volatility is more strongly associated with risk as measured by equity market-model beta, the standard deviation in stock returns, and longterm interest-rate beta, when compared to the volatility of net income.
} 
investigate about the effect of increased OCI volatility induced by recent accounting standards on creditors' perceptions of debt risk.

The asymmetric payoff structure between creditors and shareholder provides the theoretical basis for assuming that creditors' concerns about OCI's volatility may differ from shareholders. The asymmetric payoff structure between shareholders and creditors implies that creditors are not entitled to a proportionate claim on firm value when the firm value is higher than the firm's debt, whereas creditors are at most entitled to firm value when the firm value is lower than the value of the firm's debt. Therefore, this suggests that corporate decisions that contribute to firms' overall earnings volatility (i.e., decisions which increase the probability of future gains as well as future losses) impact creditors differently than shareholders. Another implication of our argument is that creditors may be especially concerned about additional income volatility captured in OCI if OCI does not have any expected positive effect on the firm's overall earnings (i.e. with zero mean). Whether or not debt contracting is influenced by OCI is the empirical question we pursue in the paper. ${ }^{6}$

When agency costs of debt are considered (Jensen and Meckling, 1976; Myers, 1977; Smith and Warner, 1979), creditors' concern regarding the value of their claims is further exacerbated when firm management acts to advance shareholders' interests at the expense of bondholders' interests. Specifically, firm management may seek to organize firms' operations and financial structure in ways that increase equity value at the expense of creditors such as committing to unexpected high-risk investments (asset substitution). Asset substitution occurs when the firm issues debt to finance investment but promises creditors the investment will be low risk investment. Then after the debt is issued, firm management 'substitutes' high risk investment. The value of

\footnotetext{
${ }^{6}$ Appendix 1 contains an illustrative theoretical model showing that when OCI has zero expected value but has positive expected correlation to the firm's future value, even risk-neutral creditors will lower the value of their claims as OCI volatility increases.
} 
shareholders' equity rises because equity benefits from the promise of higher cash flows related to the increase in the firm's risk associated with the increased expected variability of the firm's investment payoffs. However, the increased risk related to the increased variability causes creditors to face a potential decline in the expected value of their claims if increased risk causes firm value to drop below the value of debt. ${ }^{7}$ Creditors may take actions to protect themselves from the risks that anticipate the risk shifting activities. The actions we consider in this paper are: increasing the cost of financing, requiring covenants and imposing stricter maturity-leverage mix.

Due to the FASB's shift towards a comprehensive income approach, the volatility of firm's OCI-related performance measures have increased as a result of the increased number of OCI adjustments over time. One outcome is that they may be becoming more sensitive to information that reveals higher risk taking or higher degree of asset substitution concerns. Lenders should favor these measures because they tend to be more conservative (Skinner 2011). The OCI adjustments include, for example, fair value adjustments from investing or hedging and currency translation adjustments from greater internationalization of the firm's operations. Frequent adjustments to OCI resulting in higher OCI volatility can signal management's efforts to achieve asset substitution leading to a greater probability that a firm is not able to fund interest and debt repayments. Lenders'

\footnotetext{
${ }^{7}$ Asset substitution can be incorporated into the illustrative model discussed in the Appendix 1 by making the risk of the operating policy of the firm that is captured by OCI volatility as an endogenous choice instead of an exogenous event. In this case, the manager, who is acting on behalf of shareholders, has an incentive to make an investment that will introduce volatility, captured by $\delta$, to increase the value of the firm's equity at the expense of creditors. This occurs because the decrease in the value of the firm's debt amounts exactly to the increase in the value of the firm's equity (i.e. $\mathrm{k} \delta$ ). Rational creditors do expect this incentive and will price the firm's debt at a lower price and thus at a higher yield. The change in yield can be approximated by $\mathrm{k} \delta / \mathrm{B}$ for small values $\delta$ relative to $B$ and for values of $\mathrm{k}$ close to 1 . If the manager can unboundedly increase the firm's risk after the debt is cast (i.e. there is no upper bound for $\delta$ ), adverse selection dictates that rational creditors will refuse to lend to the firm. We suggest the projects that the manager might be considering, for example, are related to foreign operations associated to the current-currency adjustment to OCI, additional investments in marketable securities related to fair value adjustments to OCI or expansion of the firm's defined benefit plan.
} 
concerns about the implications of higher volatility of OCI infer the imposition of higher costs for the firm's borrowings. Therefore, we have the following expectations on the relation between the volatility of OCI and cost of debt.

HYPOTHESIS 1: The loan spread is positively related to the volatility of $O C I$.

Alternatively, when a lender is concerned about the higher volatility of OCI of a firm, the lender may decide to impose more stringent non-price related terms. For example, the lender might increase the number of loan covenants, require collateral, impose shorter maturity (Chava, Kumar and Warga, 2010; Chambers, Linsmeier, Shakespeare, Sougiannis 2007 and Graham, Li and Qiu 2008). It is important to note that management may also have an incentive to agree to restrictive covenants because rational creditors will price the loan at a lower value (or higher yield) in the absence of a commitment to restrictive covenants. ${ }^{8}$ Therefore, we have the following expectation on the relation between the volatility of OCI and flexibility of non-price related loan terms expressed in the alternative form:

HYPOTHESIS 2: The flexibility provided in non-price related loan terms is negatively related to the volatility of $\mathrm{OCI}$.

Prior research shows that debt maturity term and leverage can be simultaneously used to control for lending risk, resulting in reduced agency costs of the debt (Leland and Toft, 1996; Barnea, Haugen, and Senbet, 1980; Rajan and Winton, 1995; Johnson, 2003; Brockman, Martin, and Unlu, 2010). If creditors view increased OCI variability to be new information about the riskiness of the firms' debt, creditors may then demand a shorter maturity structure as OCI increases in volatility.

\footnotetext{
${ }^{8}$ In our illustrative model, creditors' monitoring costs should be less than $\mathrm{k} \delta$ for covenants to be agreeable by creditors. It is also important to note that in our setup OCI-based financials uncover a value-neutral operating policy. It is straightforward to suggest a construct (i.e. set $\left.p \delta_{\text {up }}<(1-p) \delta_{\text {down }}\right)$ where OCI information reveals a negative effect on the firm value and yet shareholders still have an incentive to pursue the value-destroying project at the expense of creditors because the value of their claim will always be zero when the firm defaults. In this case, restrictive covenants can improve overall firm value as discussed in Smith and Warner (1979) also named as "costly contracting hypothesis"
} 
A shorter duration of the debt structure means that creditors are better able to monitor management actions when it is revealed, for example that returns generated from investments of resources received from debt issuances may be riskier than previous expected. This increased variability may result from new accounting standards, changes in the firm's operations or from more thorough applications of past standards that subject the firm to more income items classified as OCI. The result is in a 'finer' view of the firm's activities. ${ }^{9}$

Trade-off theory predicts that firms identify their capital structure by considering benefits and costs of debt. Shortening maturity raises refinancing risk, resulting in a greater potential for inefficient liquidation of the firm (Diamond, 1991; 1993 and Sharpe, 1991) or fire-sale of firms' assets (Brunnermeier and Yogo, 2009). Firms, that have less control over the maturity of their debt and are subject to high refinancing risk, may lower their leverage to offset the negative impact of the shorter maturity. ${ }^{10}$ Our predictions about the relationships between the volatility of OCI with the maturity structure of the firm's debt and the firm's leverage leads to our third and fourth hypotheses stated in the alternative forms as follows:

HYPOTHESIS 3: The portion of short-term debt is positively related to the volatility of

\section{OCI.}

HYPOTHESIS 4: The leverage is negatively related to the volatility of OCI.

Theoretical models provide support for the role of accounting information in determining credit risk. Epstein and Schneider (2008) argue that when the implications of information is difficult to judge, investors consider signals ambiguous. Investors update their beliefs with multiple likelihoods in mind. Ambiguous information leads them to perceive a range of signal precisions, and respond based on the assessment of the worst-case scenario. Epstein and Schneider (2008)

\footnotetext{
${ }^{9}$ We use 'finer' here in the economic sense to imply more disaggregate information.

${ }^{10}$ In addition, trade-off theory predicts lower leverage in a firm that has higher susceptibility of asset substitution (Gungoraydinoglu and Öztekin, 2011).
} 
conclude that investors require higher returns for low future information quality so that the more uncertain the information quality becomes, the higher are the expected returns. ${ }^{11}$ We build on their finding that the scale of compensation for low information quality is positively related to the volatility of fundamentals to suggest that the increased volatility of OCI due to recent accounting standards may be increasing the perceived volatility of fundamentals. Higher volatility of OCI adjustments may indicate higher asset value measurement uncertainty. Therefore, increased volatility of adjustments affecting OCI implies higher likelihood of a firm to default.

As the leading information providers to debt markets, credit rating agencies may factor the OCI uncertainty into credit ratings as earnings volatility is an important factor considered in credit rating methodology (Jung, Soderstorm and Yung, 2013). OCI volatility could especially be a useful information source for credit rating agencies because it is relatively difficult for managers to manipulate OCI compared to the earnings recognized on the income statement. Consistently, Ali and Zhang (2009) and Jung, Soderstorm and Yung (2013) report that managers are more likely to strategically manipulate earnings (excluding OCI) to maximize (minimize) the firm's chances of an upgrade (a downgrade). Similarly, Alissa, Bonsall, Koharki and Penn (2013) show that incomeincreasing earnings management activities tend to occur when the firm's actual credit rating tends to be below the firm's expected credit ratings. Relying on the firm's reported income that is subject to managerial manipulation to a higher extent, credit rating agencies might use OCI-based earnings volatility in assigning the firm's credit rating. Therefore, we predict the following:

HYPOTHESIS 5: The credit rating is negatively related to the volatility of OCI.

\section{Sample, variables and research design}

\subsection{Sample construction}

\footnotetext{
${ }^{11}$ Similarly, Duffie and Lando (2001) conclude that yields spreads are strictly positive even at zero maturity if the information is imperfect. These outcomes are due to investors' uncertainty about the default risk of the company.
} 
We construct three samples to test our hypotheses. To examine the effect of OCI volatility on loan spreads, maturity and covenants, we draw data on new loan issues from Dealscan provided by Loan Pricing Corporation. Analyzing new loan issues allows us to measure the impact of OCI volatility in an incremental setting that captures the views of creditors when determining the terms of the new loan given the firm's financial health. ${ }^{12}$ Our second sample is based on the COMPUSTAT universe. We use this sample to examine the impact of OCI volatility on capital and maturity structure while controlling for potential simultaneity shown previously (Johnson, 2003; Billet, King and Mauer, 2007). This approach is an alternative to the incremental approach and captures the effect of OCI volatility on overall capital structure of the firm. A major advantage of the Dealscan sample is the availability of detailed issue specific information that is not available on COMPUSTAT, whereas a major advantage of the COMPUSTAT sample is its wider cross-sectional coverage.

For the Dealscan sample, we merge the issue-specific data to financial accounting information from COMPUSTAT. After imposing data availability requirements for variables used in the regressions and filtering out financial services firms (SIC codes between 6000 and 6999) due to their distinct regulatory environment, we get a final sample of 4,791 issue-year observations based on 1,864 unique nonfinancial firms between 2004 and 2011. Our sample coverage starts from 2004 for computation of the volatility of OCI. We limit the sample year to 2011 because the DealscanCOMPUSTAT link file is available only until 2012 (Chava and Roberts, 2008).

For the COMPUSTAT sample, we identify sample firms by merging COMPUSTAT with CRSP and by requiring the necessary financial accounting and stock return information to construct the variables used in empirical specifications. We exclude financial services firms (SIC codes

${ }^{12}$ Guedes and Opler (1996) suggest that incremental approach might be useful when determinants of debt contracting (especially debt maturity) fluctuate over time. Some of the other studies using the incremental approach are Brockman, Martin, Unlu (2010), Graham, Li and Qiu (2008), Denis and Mihov (2003), Hovakimian, Opler, and Titman (2001), and Jung, Kim, and Stulz (1996). 
between 6000 and 6999). The final sample consists of 20,905 firm-year observations based on 4,241 unique nonfinancial firms between 2004 and 2014.

For our credit rating sample, we choose firms with credit ratings from our COMPUSTAT sample. We merge the entire COMPUSTAT with CRSP firms having available data required for empirical specifications. Consistent with the first two samples, our third sample only includes nonfinancial firms. The final credit rating sample contains 9,681 firm-year observations based on 1,568 unique firms for the period from 2004 to 2014.

\subsection{Variables}

Our primary variable of interest is the volatility of OCI (STD_CHG_AOCI/A), which is defined as the standard deviation of annual changes in the accumulated other comprehensive income scaled by the book value of assets over the past five years. The variable $S T D_{-} C H G_{-} A O C I / A$ captures the volatility of income that is not reported on the income statement and parallels the standard volatility measure based on ROA used in the literature. However, unlike ROA, higher OCI volatility may indicate higher credit risk related to OCI elements such as investments, hedging, foreign currency translation and postretirement benefits.

Our summary statistics reveal that OCI volatility is substantial and important based on several measures. Specifically, we find that the average OCI volatility is almost 20 percent of the ROA volatility. More importantly, we show that OCI correlates positively to the market portfolio with an average correlation coefficient around 0.3 , which suggests that OCI volatility carries systematic risk. Though the average annual change in OCI tends to be zero, our summary statistics imply that OCI volatility may concern creditors, whose claims are wiped out when the firm is in financial trouble and are capped when the firm is financially healthy. Overall, OCI volatility appears to be a significant and unique source of income volatility which potentially influences creditors' judgments. 
To ensure robustness from potentially confounding effects, we control for three variables in every specification throughout the paper. First, we control for OCI level $\left(C H G \_A O C I / A\right)$ to capture any $\mathrm{OCI}$ income effect. Paralleling the traditionally used ROA calculation, $\mathrm{CHG}_{-} \mathrm{AOCI/A}$ is measured as the annual change in accumulated other comprehensive income scaled by assets. CHG_AOCI/A measures the profitability of the firm that is not recognized on the income statement. Second, we control for traditionally used profitability (ROA) and third for income volatility (STD_ROA) based on the earnings figures reported on the income statement. As discussed later, OCI volatility is weakly correlated, if not uncorrelated, to these three variables suggesting multicollinearity problems are unlikely to bias our estimates.

Other control variables are motivated based on past literature and vary for each sample. For the Dealscan sample, we control for growth opportunities, leverage, tangibility, firm size, zscore and various loan characteristics. In the COMPUSTAT samples, we consider asset maturity, growth opportunities, unexpected earnings, firm size, credit rating, investment tax credits and operating loss carry forward presence. The Appendix 2 provides the calculation details for all of our variables. In the next subsection, we discuss our empirical research design.

\subsection{Research design}

\subsubsection{Empirical specifications used in the Dealscan sample}

To examine the effect of OCI volatility on debt contracting, we conduct multivariate analyses on loan spread ( $\left.L O G_{-} L O A N_{-} S P R E A D\right)$, loan covenants (FIN_COV, TOT_COV), loan security (SECURED_DUM) and loan maturity (LOG_MATURITY). We use one-period ahead dependent variables to ensure that information proxied on the right hand side of the equations is known to credit markets at the time of contracting. We estimate specifications below consistent with Graham, $\mathrm{Li}$ and Qiu (2008). These specifications are single-equation reduced form equations that requires 
the exclusion of potentially jointly determined dependent variables on the right hand-side of the equations. ${ }^{13}$

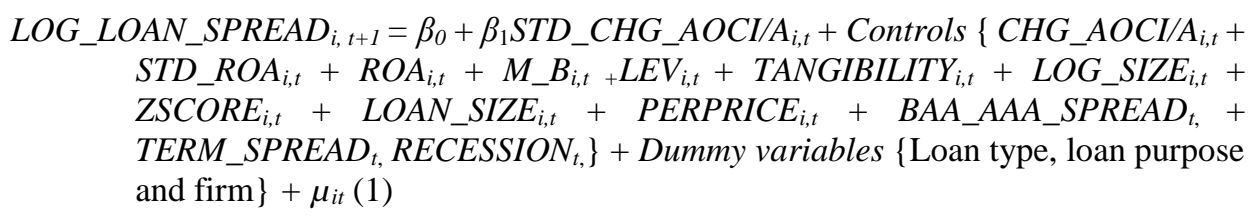

$\operatorname{Logit}\left\{\operatorname{Prob}\left(S E C U R E D \_D U M_{i, t+1}=1\right)\right\}=\theta_{0}+\theta_{1} S T D \_C H G_{-} A O C I / A_{i, t}+$ Controls $\left\{\right.$ CHG_AOCI/A $A_{i, t}+S T D \_R O A_{i, t}+R O A_{i, t}+M_{-} B_{i, t}+L E V_{i, t}+$ TANGIBILITY $_{i, t}+$ $L O G_{-}$SIZE $_{i, t}+$ ZSCORE $_{i, t}+$ LOAN_SIZE $_{i, t}+$ PERPRICE $_{i, t}+$ BAA_AAA_SPREAD $D_{t,}+$ TERM_SPREAD, RECESSION $\left.{ }_{t}\right\}+$ Dummy variables $\{$ Loan type, loan purpose and firm $\}+\delta_{i t}$

$$
\begin{aligned}
& \text { LOG_MATURITY } Y_{i, t+1}=\gamma_{0}+\gamma_{1} S T D \_C H G \_A O C I / A_{i, t}+\text { Controls }\left\{\text { CHG_AOCI/A } A_{i, t}+\right. \\
& +\zeta_{i, t}
\end{aligned}
$$

We measure $L O G \_L O A N \_S P R E A D$ as natural logarithm of the spread over LIBOR for each drawn down, consisting of the spread of the loan and any annual (or facility) fee paid to lenders. Covenant intensity is measured in two ways: FIN_COV and TOT_COV. The variable FIN_COV is the number of financial covenants in the loan agreement whereas $T O T_{-} C O V$ is the number of total covenants. SECURED_DUM is an indicator variable taking a value of one if the loan facility is secured by collateral and zero otherwise. $L O G \_M A T U R I T Y$ is natural logarithm of the loan maturity, which is measured in months.

\footnotetext{
${ }^{13}$ As discussed in detail in Section 3.3.2, past literature shows that maturity and leverage are jointly determined therefore we exclude the leverage $(L E V)$ from equation 4 and estimate a reduced-form equation. This exclusion does not have any impact on our estimates.
} 
Coefficients on STD_CHG_AOCI/A in Equation 1, 2, 3, and 4 are expected to have positive signs, suggesting that high volatility of OCI is associated with higher cost of debt, higher number of loan covenants, higher likelihood of collateralization (i.e. security) and longer loan maturity respectively. Return on assets $(R O A)$ is defined as income before extraordinary items divided by total assets at year t. STD_ROA is the standard deviation of $R O A$ based on the past five years. Market to book value $\left(M \_B\right)$ is market value of total assets divided by the book value of assets, where market value is defined as the sum of market value of equity and book value of liabilities. Leverage ( $L E V)$ is calculated as debt in current liabilities plus long-term debt divided by total assets. LOG_SIZE is measured as a natural logarithm of market value of assets. Modified Altman's (1968) Z-score (ZSCORE) is computed as follows: $1.2 *$ (WorkingCapital) $+1.4 *$ RetainedEarning $+3.3 *$ EBIT+ Sales. Modified Z-score does not include the ratio of market value of equity to book value of debt since a separate $M \_B$ variable is included in the regressions. $L O A N \_S I Z E$ is the natural logarithm of the amount of the loan measured in millions. PERPRICE is an indicator variable taking a value of one if the loan facility uses performance pricing and zero otherwise.

We consider three macroeconomic variables (BAA_AAA_SPREAD, TERM_SPREAD RECESSION) to control for economy-wide credit risk, the slope of the yield curve and lack of robust economic growth. BAA_AAA_SPREAD measures the average yield difference between AAA rated and BAA-rated bonds. All else constant, higher spread implies higher perceived default risk. TERM_SPREAD is measured as the difference between the 10-year Treasury yield and the 2-year treasury yield. Positive values of TERM_SPREAD indicates upward sloping yield curve and nearzero or negative values imply flat or inverted yield curves, which tend to occur prior to recessions. RECESSION is an indicator variable that equals to one when the loan is issued during a recessionary period as identified by National Bureau of Economic Research.

\subsubsection{Empirical specifications used in the COMPUSTAT sample}


As we indicate in our hypothesis development section, corporate finance theory predicts that the use of debt in the capital structure and the maturity of debt is jointly determined. Agency theory (Jensen and Meckling, 1976) posits that due to asymmetric payoff structure between debt and equity, financial managers, that maximize the value of the firm's equity, will be incentivized not only to reject positive NPV projects but also to accept negative NPV projects at the expense of creditors. Rational creditors anticipate these incentives and respond accordingly to protect the value of their claims. One mechanism, through which the creditor-shareholder conflict can be mitigated, is utilization of shorter-term debt (Myers, 1977). Myers (1977) argues that if debt matures before the investment opportunities, creditor-shareholder conflict can be avoided as creditors can renegotiate the terms of credit consistent with their incentives. However, a major cost of short-term debt is rollover risk, which can materialize if the firm fails to refinance the short-term debt (Diamond, 1991). In that case, the firm is required to fully pay for the debt to avoid bankruptcy. The expectation of potential rollover risk is a factor that discourages financial managers from using short-term debt heavily. Overall, theoretical studies and empirical studies suggest that debt maturity structure and leverage are likely to be jointly determined (Barclay, Marx, and Smith, 2003; Johnson, 2003; Datta, Iskandar-Datta, and Raman, 2005; Billett, King, and Mauer, 2007). To jointly test the thir $\mathrm{d}$ and fourth hypotheses, we estimate following structural equation system using 2 SLS on the COMPUSTAT sample:

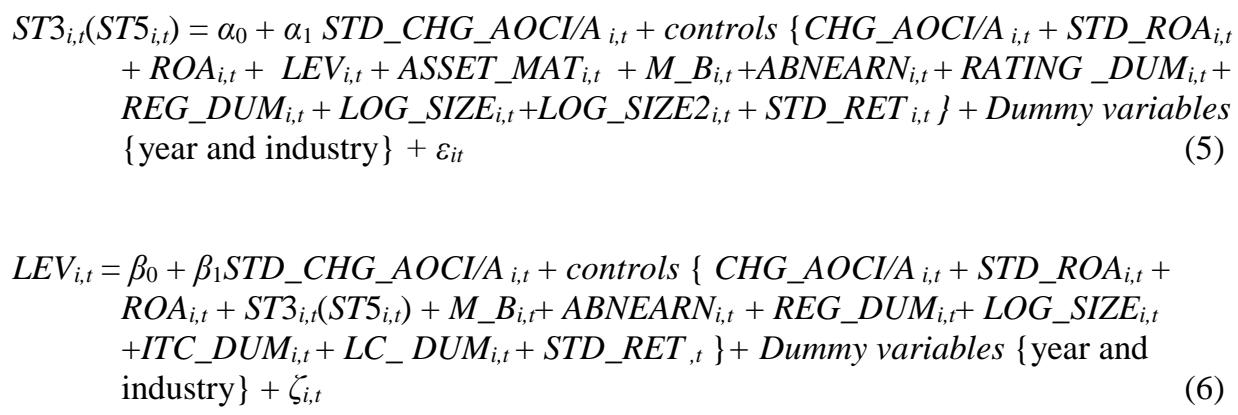


The dependent variables in the maturity equation, $S T 3$ and $S T 5$, measure the proportion of the debt maturing in three and five years. Consistent with past literature, ST3 (ST5) is defined as debt in current liabilities plus debt maturing in the second year plus debt maturing in the third year (plus fourth year plus fifth year) scaled by total debt. Total debt is defined as debt in current liabilities plus long-term debt. We expect $\alpha_{l}$ is to be positive, suggesting that high volatility of OCI is associated with the short-term maturity. The main coefficient of interest in the leverage equation is $\beta_{1}$ with an expected negative sign, suggesting that higher OCI volatility results in lower use of leverage. Consistent with the literature, leverage $(L E V)$ is measured as debt in current liabilities plus long-term debt divided by total assets. Asset maturity (ASSET_MAT) is based on Stohs and Mauer (1996) and measured as the weighted average of long-term asset maturity and current asset maturity. The maturity of long-term assets is measured as gross property, plant, and equipment (PP\&E) divided by depreciation expense while the maturity of current assets is measured as current assets divided by the cost of goods sold. Total asset maturity is the weighted sum of these measures where gross PP\&E/total assets is the weight for long-term assets and current assets/total assets is the weight for current assets. Market-to-book ratio $\left(M_{-} B\right)$ is market value of total asset divided by book value of total asset, where market value is defined as the sum of market value of equity and book value of liabilities. Abnormal earnings (ABNEARN) is the difference between earnings at year $\mathrm{t}$ and $\mathrm{t}-1$ scaled by market value of equity at year t. $R A T I N G_{-} D U M$ captures credit quality of a firm, equaling one if a firm has an S\&P rating on long-term debt, and zero otherwise. $R E G \_D U M$ equals one if the firm's SIC code is between 4,900 and 4,939, and zero otherwise. $L O G \_S I Z E$ is measured as a natural logarithm of market value of assets. $L O G \_S I Z E 2$ is the squared natural logarithm of market value of assets. Return on asset (ROA) is used to control for profitability. STD_RET is the five-year standard deviation of stock returns. ITC_DUM equals one if the firm has an investment tax credit, and zero otherwise. $L C \_D U M$ equals one if the firm has operating loss carry forward, and zero otherwise. 
To deal with the over-identification restrictions, we use the square of firm size (LOG_SIZE2), asset maturity (ASSET_MAT), the rated-firm dummy $\left(R A T I N G_{-} D U M\right)$, and expected marginal tax rate proxies $\left(L C_{-} D U M\right.$ and $\left.I T C_{-} D U M\right)$ as instrumental variables and treat the rest of the excluded variables as exogenous. Our results remain unchanged when we use the full set of excluded variables as instruments however the $p$-value for the over-identification tests become less than 10 percent and therefore we do not report those estimations in our main tables. Alternatively, we also estimate the system (unreported) using limited information maximum likelihood (LIML) method that is robust for violation of over-identification restrictions (Davidson and MacKinnon, 1993; Mariano, 2001; Angrist and Krueger, 2001; Greene, 2003) and find that our results remain robust under LIML as well.

\subsubsection{Empirical specifications used in the credit ratings sample}

Turning to the credit rating analysis, we estimate a specification similar to that in Lee (2008). Our control variables are consistent with Standard \& Poor's rating criteria and aim to capture the overall creditworthiness and the firm's capacity to satisfy its financial obligations. The ordered-logit specification is shown below:

Ordered Logit $\left\{L E A D \_R A T I N G S P_{i, t}\right\}=\beta_{0}+\beta_{1} S T D \_C H G \_A O C I / A_{i, t}+$ Controls $\left\{C H G_{-} A O C I / A_{i, t}+S T D \_R O A_{i, t}+R O A_{i, t}+I N T C O V_{i, t}+R A T I N G S P_{i, t}+L E V_{i, t}+\right.$ $\left.L O G \_S I Z E_{i, t}+S T D \_R E T_{i, t}\right\}+$ Dummy variables $\{$ year and industry $\}+\mu_{i, t}$ (7)

The dependent variable is 12 -month-ahead $\mathrm{S} \& \mathrm{P}$ credit ratings (LEAD_RATINGSP) relative to the end fiscal year month. To the extent that the credit rating agency might not immediately respond to the information embedded in volatility of OCI, we consider the 12-month-ahead rating as the dependent variable. Ratings are code numerically between 1 and 22, where 22 represents an AAA rating and 1 represents a $\mathrm{D}$ rating. We expect a positive coefficient for $\beta_{1}$ suggesting that higher OCI volatility is associated with lower credit quality. To correct for the autocorrelation in ratings, we control for the lagged credit rating score (RATINGSP). Inclusion of a persistent lagged dependent variable, however, exacerbates the collinearity problem with the firm dummies. Therefore, in this 
specification instead of using a parametric approach we control for unobserved firm-level fixed effects by clustering the standard errors at the firm level.

Other control variables are OCI level, ROA, ROA volatility, leverage, size, stock return volatility and interest coverage ratio (INTCOV). INTCOV is calculated as operating income before depreciation and interest expense divided by interest expense. Other variables are measured as previously defined. In the next section, we discuss the results of our estimations.

\section{Results}

\subsection{Tests of H1: Volatility of OCI and credit spreads}

We test the relation between volatility of OCI and credit spreads using the Dealscan sample. Table 1 provides summary statistics for the Dealscan sample. A review of loan characteristics found in Panel A shows that the average loan has 202 basis points spread over LIBOR with an average size of 2.9 million dollars. A loan agreement contains two financial covenants on average and matures in 4.2 years ( 52 months). While 65 percent of the loans have a security provision, 77 percent of them contain performance pricing provisions.

Turning to firm characteristics, we find that the average ROA, market-to-book and leverage are 3.0 percent, 1.73 and 16.5 percent respectively. The average log-size of 0.728 corresponds to a firm size of USD 2.07 billion, suggesting that Dealscan sample coverage is somewhat skewed towards larger firms relative to that of COMPUSTAT sample (median firm size in COMPUSTAT sample is $\$ 1.5$ billion). Regarding the industry breakdown of the sample, manufacturing industry (1-digit SIC = 2 and 3) represents more than 40 percent of the sample firms, while agriculture industry has the smallest presence at 0.48 percent. These statistics are comparable to previous studies utilizing Dealscan data.

Panel C provides Pearson correlation coefficient estimates among OCI-based and traditional measures of income level and volatility. Our primary variable of interest, STD_CHG_AOCI/A, is not statistically significantly correlated to $(\rho=-0.011)$ ROA volatility 
(STD_ROA), suggesting that information content of these two variables do not overlap. Therefore, any information that OCI volatility captures is unlikely to be reflected by ROA volatility. ${ }^{14}$ The strongest correlation occurs between $S T D \_R O A$ and $R O A$ at -0.311 followed by the correlation between OCI volatility and OCI level at -0.110 . Both of these coefficients are statistically and economically less than 1 , suggesting that information content of these variables are sufficiently distinct from each other.

Lastly, Panel D provides the average and median figures for the firm-level Pearson correlation coefficients (CORR_OCI_VWCRSP) between OCI $\left(C H G \_A O C I / A\right)$ and market returns (based on CRSP value-weighted returns) estimated over the previous five years. Contrary to the noise view, we find that $\mathrm{OCI}$ is positively related to market returns. The average and median correlation estimates are 0.351 and 0.453 and these estimates are statistically significant based on $t$ test and Wilcoxon rank test $(p$-value $=0.000)$. Positive OCI correlation to the market returns suggests that OCI carries systematic risk, which should be a concern to the firm's creditors.

Table 2 reports the estimation results for the credit spread regressions. Model 1 considers only OCI-based and traditional measures of income level and volatility and fixed effects. Model 2 adds the firm and loan characteristics with loan type, purpose and firm effects. Model 3 and 4 add the macroeconomic variables. In all four models, we find that OCI volatility is positively and significantly related to credit spreads.

These results are economically significant both on a relative and absolute basis. It is important to note that $\mathrm{OCI}$ volatility coefficient estimates $\left(S T D_{-} C H G_{-} A O C I / A\right)$ are substantially larger than those for ROA volatility $\left(S T D \_R O A\right)$. This suggests that for a 1 percent change in OCI versus ROA volatility, loan spreads will be much more sensitive to OCI volatility than to ROA

\footnotetext{
${ }^{14}$ Whether the information content of OCI volatility is purely noise is the empirical question we pursue in the paper and, our evidence implies that OCI volatility provides useful risk-related information to credit markets.
} 
volatility. ${ }^{15}$ More specifically, Model 4 results suggest that log-spreads are much for sensitive to OCI volatility relative to ROA volatility by a factor of $10.45(3.962 / 0.379=10.45)$. Therefore, holding the size of the change constant, it is clear that credit spreads are more highly sensitive to OCI volatility than they are to ROA volatility.

When economic significance is evaluated on an absolute basis, we find that when OCI volatility increases from 5 percent to 95 percent of the sample distribution, spreads increase by roughly 17 percent, which implies an increase of $34 \mathrm{bps}(30 \mathrm{bps})$ for the mean (median) spread of 202 (175) bps. For the similar increase in ROA volatility, Model 4 results suggest that credit spreads increase by 1.6 percent or $3.2 \mathrm{bps}(2.8 \mathrm{bps})$ based on the sample mean (median). These findings suggest that OCI volatility is priced as a risk factor into credit spreads and thus are not treated as pure noise by creditors.

\subsection{Tests of $\mathrm{H2}$ : volatility of $\mathrm{OCI}$ and non-price related terms of loan agreements}

In this section, we examine how other aspects of debt contracting might be affected due to OCI volatility. If creditors demand higher spreads due to higher OCI volatility, they might also require tighter covenants, collateral posting or shorter maturities. Table 3 presents our estimation results.

Models 1 and 2 of Table 3 show that OCI volatility is not statistically significantly related to covenant intensity. Given the results in Demerjian (2011) that balance sheet covenants have lost their popularity in the past decade, we reconstruct the dependent variable by only counting the balance sheet covenants (i.e. net worth, debt ratio) and find that OCI volatility remains unrelated to balance sheet-based covenant intensity. We do not find a statistically significant relation between ROA volatility and covenant intensity, although the slope coefficient has the expected positive sign.

Model 3 shows the estimation results for the logit specification, modeling the probability of collateral presence in the loan agreement. Similar to credit spread results, we find that both OCI-

\footnotetext{
${ }^{15}$ We realize that 1 percent change in volatility is less likely to occur for OCI volatility compared to ROA volatility.
} 
based and traditional income volatility measures are positively related to the presence of collateral. More importantly, collateral presence is much more sensitive to OCI volatility $\left(\theta_{l}=45.576\right)$ relative to ROA volatility (coefficient estimate for $S T D_{-} R O A=11.045$ ). Turning to the economic significance, when OCI volatility changes from 5 percent to 95 percent of the empirical distribution, probability of collateral requirement increases from 52 percent to 88 percent, which is economically significant given that the unconditional probability of observing collateral requirement is 65.2 percent. ${ }^{16}$

Finally, Model 4 of Table 3 shows the results of the loan maturity regressions. We find that income volatility (neither OCI-based nor traditional) does not have a statistically significant influence on loan maturity. Credit spread, term spread and loan size appear to be the factors that are significantly related to loan maturity with expected signs.

Overall, our analyses based on incremental empirical setting suggest that creditors use cost of borrowing and requiring collateral as their primary tool in responding to high OCI volatility. We do not find statistically significant evidence that covenants and loan maturity are used to mitigate the risk captured by OCI volatility. Taken together, these results support the view that OCI volatility provides useful risk-related information to creditors.

\subsection{Tests of $\mathrm{H} 3$ and H4: volatility of $\mathrm{OCI}$ with maturity and capital structure}

We start our analyses by providing summary statistics for the COMPUSTAT sample. Panel A of Table 4 shows the distributional characteristics of the variables used in simultaneous equation specifications. The average for ST3 and ST5 are 44 percent and 62 percent, confirming the heavy use of short-term debt in corporate capital structure. These statistics are consistent with Harford,

\footnotetext{
${ }^{16}$ We evaluate predicted probabilities based on the coefficient estimates of Model 3 in Table 3. The non-linearity of logit specification requires calibrating a baseline model. We calibrate the baseline model using the mean values of the right-hand side variables. To ensure that fixed effects do not skew the predicted probability of the baseline model, we calibrate the fixed effects so that the predicted probability equals to the unconditional probability of collateral requirement (i.e. 65.2 percent).
} 
Klasa and Maxwell (2014), who report a secular increase in the use of short-term debt between 1980 and 2007 for a large sample of US firms.

We find that the distributions of earnings level and volatility measures are quite comparable to those of the Dealscan sample. Specifically, the averages (medians) for $S T D \_C H G \_A O C I / A$ and STD_ROA are 1.4 percent ( 0.6 percent) and 10.2 percent (3.9 percent) respectively and the averages (medians) for $C H G \_A O C I / A$ and $R O A$ are -0.02 percent ( 0 percent) and -2.1 percent ( 3.5 percent) respectively. Regarding other firm characteristics, the average (median) for LEV, ASSET_MAT, $M \_B, A B N E A R N$, is $0.25(0.22), 11.9(7.06), 1.80(1.44)$ and $0.01(0.004)$ respectively. These statistics are comparable to those reported in the prior literature and for the Dealscan sample.

Panel B shows the correlation coefficient estimates among the conventional and OCI-based profitability and volatility measures in the COMPUSTAT sample. We find that the correlation structure is virtually similar to that of the Dealscan sample. Most importantly, OCI volatility ( $\left.S T D \_C H G \_A O C I / A\right)$ is not correlated to ROA volatility ( $\left.S T D \_R O A\right)$, suggesting that OCI volatility does not reflect the same information content of ROA volatility.

Panel C confirms the positive correlation structure between OCI and market returns for the Compustat sample. Specifically, the average and median values for the firm-level correlation between $\mathrm{OCI}$ and market returns are 0.289 and 0.338 , which are statistically significant at 1 percent $(p$-value $=0.000)$. Consistent with the Dealscan sample, we conclude that OCI carries systematic risk and is a potentially useful source of information for creditors.

Panel D of Table 4 reports the annual average figures for OCI volatility (first row for STD_CHG_AOCI/A) and OCI-component volatility (bottom five rows). COMPUSTAT subcategorizes accumulated other comprehensive income under five categories: (1) unrealized derivative gains/losses, (2) pension/postretirement adjustments, (3) adjustments to marketable securities, (4) translation adjustments and (5) other adjustments not included in the previous components. To ensure comparability to $S T D_{-} C H G_{-} A O C I / A$, we calculate the component volatility 
measures over the past five years for annual changes in the components scaled by the book value of assets. $^{17}$

It appears that average overall OCI volatility (STD_CHG_AOCI/A) increases from 0.8 percent in 2004 to 1.2 percent in 2014, while peaking at 1.7 percent between 2008 and 2011. This pattern is largely applicable for all component volatilities except for $S T D \_C H G \_D E R I / A$ and STD_CHG_OTHER/A that seem to have a flat trend. Volatilities of pension/post-retirement adjustments $\left(S T D \_C H G \_P E N / A\right)$ and translation adjustments $\left(S T D \_C H G_{-} T R A N S / A\right)$ appear to be the main drivers of the OCI volatility.

Panel E of Table 4 shows the industry distribution of our sample based on 1-digit SIC codes. Consistent with prior literature, manufacturing firms (1-digit SIC = 2 and 1-digit SIC $=3$ ) make up roughly 50 percent of the sample whereas, agriculture $(N=83)$ and public administration services ( $N=467$ industries contribute the least to the sample.

Table 5 reports the simultaneous equation results for maturity and leverage related to $\mathrm{H} 3$ and H4. In both panels, Columns 1 and 2 provide coefficient estimates for the short-maturity and leverages equations respectively. In Panel A, short-term debt maturity is proxied by the proportion of debt maturing in three years (ST3) whereas in Panel B, ST5 is used. In the maturity equation of Panel A, the coefficient on STD_CHG_AOCI/A is positive $\left(\alpha_{l}=0.359\right)$ and significant at 1 percent ( $p$-value $=0.002)$, which is consistent with $\mathrm{H} 3$. This finding suggests that holding the leverage amount constant, maturity of debt in the capital structure declines as the volatility of OCI increases. Put differently, creditors are less likely to fund the firm with long-term debt as OCI volatility increases. Turning to the leverage equation, we find that a negative $\left(\beta_{l}=-0.341\right)$ and significant

\footnotetext{
${ }^{17}$ For variable names, we use the similar mnemonics as in OCI volatility (STD_CHG_AOCI/A) for OCI components. STD_CHG_DERI/A, STD_CHG_PEN/A, STD_CHG_MSA/A, $S T D \_C H G_{-} T R A N S / A$ and $S T D \_C H G_{-} O T H E R / A$ are used to name unrealized derivative gains/losses, pension/postretirement adjustments, adjustments to marketable securities, translation adjustments and other adjustments respectively.
} 
relation at 1 percent $(p$-value $=0.000)$ between OCI volatility and leverage, which is consistent with H4. Paralleling the maturity results, these findings suggest that, holding maturity structure of debt constant, high-risk borrowers identified by high OCI volatility can borrow less from credit markets, reflecting creditors' concerns about risk.

In Panel B, we find similar results using the maturity measure of ST5. In the maturity equation, the slope coefficient for STD_CHG_AOCI/A is positive $\left(\alpha_{l}=0.286\right)$ is positive and significant at 5 percent $(p$-value $=0.020)$. In the leverage equation, we find that $S T D \_C H G \_A O C I / A$ is negatively and significantly $\left(\beta_{l}=-0.350\right.$ and $p$-value $\left.=0.000\right)$ related to leverage. Coefficients on control variables are generally consistent with the prior research (Johnson, 2003; Datta, Iskandar-Datta, and Raman, 2005; Billett, King, and Mauer, 2007).

Regarding the economic significance of OCI volatility-maturity relation, we find that when OCI volatility changes from 5 percent to 95 percent of the sample distribution, ST3 and ST5 increase by 1.8 percent and 1.5 percent respectively. Given the median levels of 34 percent and 67 percent for ST3 and ST5, we believe that these results are weakly significant. However, when we evaluate the economic significance for the effect of OCI volatility on leverage, we find that leverage decreases by roughly 1.8 percent when OCI increases from 5 percent to 95 percent of the sample distribution. Given that the median leverage is 22.4 percent in the COMPUSTAT sample, we conclude that the effect of OCI volatility on leverage is economically significant, supporting the view that credit becomes less available for firm with significant OCI volatility.

Overall our results suggest that, volatility of OCI influences the firm's capital structure. Specifically, when faced with high-risk borrowers as revealed by high OCI volatility creditors protect the value of their claims primarily by reducing their exposure to the firm and secondarily by imposing shorter maturities. The results support our claim that the volatility of fair value adjustments plays an important role in shaping the firm's capital structure.

\subsection{Tests of H5: volatility of $O C I$ and credit ratings}


Table 6 reports descriptive statistics for the credit rating sample. Panel A shows the mapping scale used in assigning credit ratings ranging from AAA $(R A T I N G S P=22)$ to $\mathrm{D}(R A T I N G S P=1)$ and Panel B shows the summary statistics used in the sample. The credit ratings sample coverage is skewed for large firms as the median firm size is $\$ 633$ million. This bias is expected as small firms tend not to get credit ratings. The mean (median) of RATINGSP is 11.47 (11.00), indicating that more than half of the sample firms have above- investment grade credit rating. Regarding volatility and profitability variables, the mean (median) for $S T D \_C H G \_A O C I / A$ and $S T D \_R O A$ are 1.7 percent (1.0 percent) and 4.6 percent (2.6 percent) and, the mean (median) of $C H G_{-} A O C I / A$ and $R O A$ are -0.2 percent ( 0.0 percent) and 3.6 percent ( 4.2 percent). In unreported results, we verify that the correlation structure among these variables as well as the sample industry distribution are virtually the same as the Dealscan and less restricted COMPUSTAT samples. Next, we discuss the ordered-logit regression results in Table 7.

Consistent with our previous findings, we show that the coefficient on $S T D \_C H G \_A O C I / A$ is negative and significant, indicating that the higher OCI volatility is associated with the lower credit ratings. This finding contrasts with our results for ROA volatility where we find no statistically significant association between ROA volatility and credit ratings. We also find that both OCI $(C H G / A O C L / A)$ and ROA $(R O A)$ are positively related to credit ratings, suggesting that credit ratings are sensitive to both OCI-based and traditional measures of income. Most of the other control variables have the expected signs. Specifically, we find that higher lagged-credit ratings, lower leverage and larger firm size are associated to higher credit ratings.

When we evaluate the economic significance, we find that economic significance of the credit rating results is marginal. When OCI volatility changes from 5 percent to 95 percent of the sample distribution, odds of a notch increase in credit ratings credit ratings (LEAD_RATINGSP) decline by 12.2 percent. Overall, we conclude that although publicly available credit ratings are 
somewhat sensitive to OCI volatility, it appears that the privately generated information by credit markets has a strong influence on debt contracting.

\section{Conclusion}

In this study we investigate the association between risk information contained in other comprehensive income (OCI) and the firm's cost of debt, non-price terms of debt contracting, capital and maturity structure and credit ratings. We explore the relationship by conducting tests with three different samples: a Dealscan sample based on new loan issues, a comprehensive COMPUSTAT sample and a credit ratings sample. The sample period is from 2004 to 2014 . We find that higher volatility of OCI is statistically and economically significantly associated with high cost of debt, higher probability of collateral requirements and lower use of debt. We also find statistically significant but economically weak evidence that higher OCI volatility is related to shorter debt maturity and lower credit ratings. Our evidence disagrees with the view that OCI-based income is predominantly noise to creditors. Rather, our results suggest that OCI-based income provides useful information to credit markets and influences various aspects of debt contracting. Our paper contributes to the literature by documenting statistically and economically significant effects of OCI volatility on the debt contracting environment. We also contribute support to the continued interest by the FASB and IASB to provide OCI reporting guidance that focuses on the needs of creditors. 


\section{Appendix 1 \\ An Illustrative Model}

One can show that even if creditors are risk-neutral and agency costs are absent, any additional income volatility captured by OCI volatility (with zero expectation), that carries systematic risk, will reduce the value of creditors' claims. In the spirit of Fama and Miller (1972), a simple oneperiod model might be useful to illustrate our point. Consider the financing problem of a firm that will operate for one year and then be liquidated at the end of the year. The firm will issue debt that will be paid back in one year with face value of B. Initially, investors form their expectations about the future firm values by analyzing the firm's non-OCI related information set. We assume that the future value of the firm can attain two possible values of $\mathrm{V}_{\text {up }}$ and $\mathrm{V}_{\text {down }}$ with probabilities of $\mathrm{p}$ and 1-p respectively. To ensure that the firm's debt is risky, we require that $\mathrm{B}>\mathrm{V}_{\text {down. }}$. In the up-state shareholders (creditors) get $\mathrm{V}_{\text {up }}-\mathrm{B}$ (B) and in the down-state shareholders (creditors) get 0 ( $\left.\mathrm{V}_{\text {down }}\right)$ as there are no bankruptcy costs. The fair values of the firm's equity and debt will be the present value of next year's expected payoff discounted at the appropriate rate, therefore:

Value of equity when OCI information is unaccounted for $=\mathrm{k}\left[\mathrm{p}\left(\mathrm{V}_{\mathrm{up}}-\mathrm{B}\right)+(1-\mathrm{p})(0)\right]=\mathrm{kp}\left(\mathrm{V}_{\mathrm{up}}-\right.$ B)

Value of debt when OCI information is unaccounted for $=\mathrm{k}\left[\mathrm{pB}+(1-\mathrm{p})\left(\mathrm{V}_{\mathrm{down}}\right)\right]$

Value of the firm $=$ The sum of the values of equity and debt $=k\left[p V_{\text {up }}+(1-p) V_{\text {down }}\right]$ where $\mathrm{k}=1 /(1+\mathrm{r})$ and $\mathrm{r}$ is the appropriate annual risk-free rate. We assume risk-neutrality for capital market participants therefore the appropriate discount rate becomes the risk-free rate. Imposing riskaversion, makes our predictions stronger as the discount rate will be higher than the risk-free rate since the current price will reflect additional discounting due to risk-aversion. Suppose that the firm's operating policies imply that the true liquidation value of the firm's assets can attain $\mathrm{V}_{\text {up }}+$ $\delta_{\text {up }}$ and $\mathrm{V}_{\text {down }}-\delta_{\mathrm{d}}$ in the up and down states respectively. More importantly, we assume that expectations using this additional piece of information can only be formed by analyzing OCI-related financial statements. To ensure that OCI has zero expected effect on the firm value (consistent with 
the empirical evidence), we set $\delta_{\text {up }}=\delta / p$ and $\delta_{\text {down }}=\delta /(1-p)$, where $\delta>0$. $\delta$ captures the magnitude of expected OCI volatility as it is directly proportional to OCI volatility (i.e. Standard deviation of OCI $\left.=\left[p(\delta / p)^{2}+(1-p)[\delta /(1-p)]^{2}\right]^{1 / 2}=\delta /[p(1-p)]^{0.5}\right)$. Consistent with the findings in Panel D of Table 1 and Panel C of Table 4, this perturbation structure ensures that OCI is positively related to the firm's value or OCI reveals information that contributes to the firm's systematic risk (i.e. asset value is larger (lower) at the up-state (down-state) when market portfolio tends to be higher (lower) consistent with the stylized evidence that typical stock has a positive beta.

When OCI information is accounted for, the values of the claims will be as follows:

Value of equity when OCI information is accounted for $=\mathrm{k}\left[\mathrm{p}\left(\mathrm{V}_{\mathrm{up}}-\mathrm{B}+\delta / \mathrm{p}\right)+(1-\mathrm{p})(0)\right]=\mathrm{kp}\left(\mathrm{V}_{\text {up }}\right.$ $-\mathrm{B})+\mathrm{k} \delta$

Value of debt when OCI information is accounted for $=\mathrm{k}\left[\mathrm{pB}+(1-\mathrm{p})\left(\mathrm{V}_{\mathrm{down}}-\delta /(1-\mathrm{p})\right]=\mathrm{k}[\mathrm{pB}+\right.$ $\left.(1-\mathrm{p})\left(\mathrm{V}_{\text {down }}\right)\right]-\mathrm{k} \delta$

In order to conclude that creditors will be concerned about OCI volatility, it suffices to show that the fair value of the debt declines when creditors account for the information content of OCI. When OCI information is considered, the decline in the fair value of the debt can be stated as:

Decrease in the value of debt when OCI information is accounted for $=\mathrm{k} \delta$

Overall, when creditors account for OCI volatility, the value they assess for the firm's debt declines and this decline is proportional to the expected magnitude of OCI volatility. 


\title{
Appendix 2
}

\section{Variable Definitions}

\author{
Main treatment variable of interest \\ $S T D \_C H G \_A O C I /$ \\ A \\ Standard deviation of CHG_AOCI/A based on the past five years.
}

\begin{abstract}
Variables used in the Dealscan sample
Dependent variables

LOG_LOAN_SPREA

$D$

FIN_COV

TOT_COV

SECURED_DUM

LOG_MATURITY

Natural logarithm of the spread over LIBOR for each dollar drawn down, consisting of the spread of the loan and any annual (or facility) fee paid to the bank group.

The number of financial covenants in the loan agreement.

The number of total covenants in the loan agreement.

An indicator variable taking a value of one if the loan facility is secured by collateral and zero otherwise.

Natural logarithm of the loan maturity. Maturity is measured in months.
\end{abstract}

Control variables

CHG_AOCI/A

STD_ROA

$R O A$

$M \_B$

$L E V$

TANGIBILITY

LOG_SIZE

ZSCORE

LOAN_SIZE

PERPRICE

BAA_AAA_SPREAD

TERM_SPRED

RECESSION

Loan type dummies

Loan purpose

dummies

CORR_OCI_VWCRS

$P$

Change (from year t-1 to t) in accumulated other comprehensive income scaled by total assets at year $\mathrm{t}$.

Standard deviation of ROA based on the past five years.

Income before extraordinary items divided by total assets at year $\mathrm{t}$.

Market value of total assets divided by the book value of assets, where

market value is defined as the sum of market value of equity and book value of liabilities.

Debt in current liabilities plus long-term debt divided by total assets.

Net property, plant and equipment divided by total assets.

Natural logarithm of market value of assets in USD billions. Market value of assets is calculated as the sum of market value of equity and book value of liabilities as of the fiscal year end.

Modified Altman's (1968) Z-score: 1.2*(Working Capital)+ 1.4* Retained Earnings $+3.3 *$ EBIT+ Sales.

Natural logarithm of the loan size. Size is measured as loan facility amount in million dollars.

An indicator variable taking a value of one if the loan facility uses performance pricing and zero otherwise.

The difference between average yields of BAA and AAA rated bonds. The difference between 10-year Treasury yield and the 2-year treasury yield.

An indicator variable taking a value of one if the observation occurs in a recession.

Dummy variables for different loan types.

Dummy variables for different loan purposes.

Correlation coefficient between contemporaneous OCI and market returns (based on CRSP value-weighted index) calculated over the past five years. 


\begin{tabular}{|c|c|}
\hline \multicolumn{2}{|c|}{$\begin{array}{l}\text { Variables used in the COMPUSTAT sample } \\
\text { Dependent variables }\end{array}$} \\
\hline ST3 (ST5) & $\begin{array}{l}\text { Debt in current liabilities plus debt maturing in the second year plus } \\
\text { debt maturing in the third year (plus those of in the fourth and fifth } \\
\text { years) scaled by total debt. Total debt is defined as debt in current } \\
\text { liabilities plus long-term debt. }\end{array}$ \\
\hline $\begin{array}{l}\text { LEV } \\
\text { Control variables }\end{array}$ & Debt in current liabilities plus long-term debt divided by total assets. \\
\hline CHG_AOCI/A & $\begin{array}{l}\text { Change (from year } t-1 \text { to } t \text { ) in accumulated other comprehensive } \\
\text { income scaled by total assets at year } t \text {. }\end{array}$ \\
\hline$S T D \_R O A$ & Standard deviation of ROA based on the past five years. \\
\hline$R O A$ & \\
\hline$A B N E A R N$ & $\begin{array}{l}\text { (Earnings at year } \mathrm{t} \text { - earnings at year } \mathrm{t}-1) / \text { market value of equity at } \\
\text { year } \mathrm{t} \text {. }\end{array}$ \\
\hline$A S S E T \_M A T$ & $\begin{array}{l}\text { The maturity of long-term assets is measured as gross property, plant, } \\
\text { and equipment (PP\&E) divided by depreciation expense while the } \\
\text { maturity of current assets is measured as current assets divided by the } \\
\text { cost of goods sold. Total asset maturity is the weighted sum of these } \\
\text { measures where (gross PP\&E/total assets) is the weight for long-term } \\
\text { assets and (current assets/total assets) is the weight for current assets. }\end{array}$ \\
\hline ITC_DUM & $\begin{array}{l}\text { An indicator variable taking a value of one if the firm has an } \\
\text { investment tax credit, and zero otherwise. }\end{array}$ \\
\hline$L C \_D U M$ & $\begin{array}{l}\text { An indicator variable taking a value of one if the firm has operating } \\
\text { loss carry forward, and zero otherwise. }\end{array}$ \\
\hline$L O G \_S I Z E$ & $\begin{array}{l}\text { Natural logarithm of market value of assets in USD billions. Market } \\
\text { value of assets is calculated as the sum of market value of equity and } \\
\text { book value of liabilities as of the fiscal year end. }\end{array}$ \\
\hline LOG_SIZE2 & Squared natural logarithm of the market value of assets. \\
\hline$M \_B$ & $\begin{array}{l}\text { Market value of total assets divided by the book value of assets, } \\
\text { where market value is defined as the sum of market value of equity } \\
\text { and book value of liabilities. }\end{array}$ \\
\hline$R A T I N G \_D U M$ & $\begin{array}{l}\text { An indicator variable taking a value of one if the firm has an } S \& P \\
\text { long-term debt rating, and zero otherwise. }\end{array}$ \\
\hline$R E G \_D U M$ & $\begin{array}{l}\text { An indicator variable taking a value of one if the firm's SIC code is } \\
\text { between } 4,900 \text { and } 4,939 \text {, and zero otherwise. }\end{array}$ \\
\hline$S T D \_R E T$ & $\begin{array}{l}\text { Standard deviation of monthly stock returns during the past five } \\
\text { years. }\end{array}$ \\
\hline CORR_OCI_VWCRSP & $\begin{array}{l}\text { Correlation coefficient between contemporaneous OCI and market } \\
\text { returns (based on CRSP value-weighted index) calculated over the } \\
\text { past five years. }\end{array}$ \\
\hline
\end{tabular}

Variables used in the credit rating sample

Dependent variable

LEAD_RATINGSP

12-month-ahead long-term S\&P rating relative to the fiscal year end.

Control variables

CHG_AOCI/A

Change (from year t-1 to t) in accumulated other comprehensive income scaled by total assets at year $\mathrm{t}$. 
STD_ROA

$R O A$

INTCOV

$L E V$

LOG_SIZE

RATINGSP

STD_RET
Standard deviation of ROA based on the past five years.

Income before extraordinary items divided by total assets at year $t$.

Operating income before depreciation and interest expense divided by interest expense at year $t$.

Debt in current liabilities plus long-term debt divided by total assets.

Natural logarithm of market value of assets in USD billions. Market

value of assets is calculated as the sum of market value of equity and book value of liabilities as of the fiscal year end.

Current long-term S\&P rating at the fiscal year end.

Standard deviation of stock returns during the past five years. 


\section{References}

Ali, A., and W. Zhang. 2009. Proximity to broad credit rating change and conservatism in reported earnings.

Alissa, W., S. B. Bonsall, K. Koharki, and M. W. Penn. 2013. Firms' use of accounting discretion to influence their credit ratings. Journal of Accounting and Economics 55 (2): 129-147.

Angrist, J. D. and A. B. Krueger. 2001. Instrumental variables and the search for identification: from supply and demand to natural experiments. Journal of Economic Perspectives 15: 69-85.

Armstrong, C. S., W. R. Guay, and J. P. Weber. 2010. The role of information and financial reporting in corporate governance and debt contracting. Journal of Accounting and Economics 50 (2): $179-234$.

Ball, R., R. M. Bushman, and F. P. Vasvari. 2008. The debt-contracting value of accounting information and loan syndicate structure. Journal of accounting research 46 (2): 247-287.

Barclay, M. J., L. M. Marx, and C. W. Smith. 2003. The joint determination of leverage and maturity. Journal of corporate finance 9 (2): 149-167.

Barnea, A., R. A. Haugen, and L. W. Senbet. 1980. A rationale for debt maturity structure and call provisions in the agency theoretic framework. the Journal of Finance 35 (5): 1223-1234.

Billett, M. T., T. D. KING, and D. C. Mauer. 2007. Growth opportunities and the choice of leverage, debt maturity, and covenants. The Journal of Finance 62 (2): 697-730.

Black, D. E. 2016. Other comprehensive income: a review and directions for future research. Accounting \& Finance. 
Brockman, P., X. Martin, and E. Unlu. 2010. Executive compensation and the maturity structure of corporate debt. The Journal of Finance 65 (3): 1123-1161.

Brunnermeier, M. K., and M. Yogo. 2009. A note on liquidity risk management.

Chambers, D., T. J. Linsmeier, C. Shakespeare, and T. Sougiannis. 2007. An evaluation of SFAS No. 130 comprehensive income disclosures. Review of Accounting Studies 12 (4): 557-593.

Chava, S., P. Kumar, and A. Warga. 2010. Managerial agency and bond covenants. Review of Financial Studies 23 (3): 1120-1148.

Chava, S., and M. R. Roberts. 2008. How does financing impact investment? The role of debt covenants. The Journal of Finance 63 (5): 2085-2121.

Datta, S., M. ISKANDAR-DATTA, and K. Raman. 2005. Managerial stock ownership and the maturity structure of corporate debt. The Journal of Finance 60 (5): 2333-2350.

Davidson, R., and J. G. MacKinnon. 1993. Estimation and inference in econometrics.

Demerjian, P. R. 2011. Accounting standards and debt covenants: Has the "balance sheet approach" led to a decline in the use of balance sheet covenants?. Journal of Accounting and Economics 52 (2): 178-202.

Denis, D. J., and V. T. Mihov. 2003. The choice among bank debt, non-bank private debt, and public debt: evidence from new corporate borrowings. Journal of Financial Economics 70 (1): 328.

Dhaliwal, D., K. Subramanyam, and R. Trezevant. 1999. Is comprehensive income superior to net income as a measure of firm performance?. Journal of Accounting and Economics 26 (1): 43-67. 
Diamond, D. W. 1991. Debt maturity structure and liquidity risk. The Quarterly Journal of Economics: 709-737.

Diamond, D. W. 1993. Seniority and maturity of debt contracts. Journal of Financial Economics 33 (3): $341-368$.

Duffie, D., and D. Lando. 2001. Term structures of credit spreads with incomplete accounting information. Econometrica 69 (3): 633-664.

Epstein, L. G., and M. Schneider. 2008. Ambiguity, information quality, and asset pricing. The Journal of Finance 63 (1): 197-228.

Fama, E. F., and M. H. Miller. 1972. The theory of finance: Dryden Press Hinsdale, IL.

Graham, J. R., S. Li, and J. Qiu. 2008. Corporate misreporting and bank loan contracting. Journal of Financial Economics 89 (1): 44-61.

Greene, W. H. 2003. Econometric analysis: Pearson Education India.

Guedes, J., and T. Opler. 1996. The determinants of the maturity of corporate debt issues. the Journal of Finance 51 (5): 1809-1833.

Gungoraydinoglu, A., and Ö. Öztekin. 2011. Firm-and country-level determinants of corporate leverage: Some new international evidence. Journal of Corporate Finance 17 (5): 1457-1474.

Harford, J., S. Klasa, and W. F. Maxwell. 2014. Refinancing risk and cash holdings. The Journal of Finance 69 (3): 975-1012. 
Hodder, L. D., P. E. Hopkins, and J. M. Wahlen. 2006. Risk-relevance of fair-value income measures for commercial banks. The Accounting Review 81 (2): 337-375.

Holthausen, R. W., and R. L. Watts. 2001. The relevance of the value-relevance literature for financial accounting standard setting. Journal of Accounting and Economics 31 (1): 3-75.

Hovakimian, A., T. Opler, and S. Titman. 2001. The debt-equity choice. Journal of Financial and Quantitative analysis 36 (01): 1-24.

Huang, H., S. Lin, and K. Raghunandan. 2015. The Volatility of Other Comprehensive Income and Audit Fees. Accounting Horizons 30 (2): 195-210.

Jensen, M. C., and W. H. Meckling. 1976. Theory of the firm: Managerial behavior, agency costs and ownership structure. Journal of Financial Economics 3 (4): 305-360.

Johnson, S. A. 2003. Debt maturity and the effects of growth opportunities and liquidity risk on leverage. Review of Financial Studies 16 (1): 209-236.

Jones, D. A., and K. J. Smith. 2011. Comparing the value relevance, predictive value, and persistence of other comprehensive income and special items. The Accounting Review 86 (6): 2047-2073.

Jung, B., N. Soderstrom, and Y. S. Yang. 2013. Earnings smoothing activities of firms to manage credit ratings. Contemporary Accounting Research 30 (2): 645-676.

Jung, K., Y. Kim, and R. Stulz. 1996. Timing, investment opportunities, managerial discretion, and the security issue decision. Journal of Financial Economics 42 (2): 159-186. 
Lee, Y. 2008. The effects of employee stock options on credit ratings. The Accounting Review 83 (5): 1273-1314.

Leland, H. E., and K. B. Toft. 1996. Optimal capital structure, endogenous bankruptcy, and the term structure of credit spreads. The Journal of Finance 51 (3): 987-1019.

Mariano, R. S. 2001. Simultaneous equation model estimators: Statistical properties and practical implications. A companion to theoretical econometrics: 122-143.

Myers, S. C. 1977. Determinants of corporate borrowing. Journal of Financial Economics 5 (2): $147-175$.

Rajan, R. G. 1992. Insiders and outsiders: The choice between informed and arm's-length debt. The Journal of Finance 47 (4): 1367-1400.

Rajan, R., and A. Winton. 1995. Covenants and collateral as incentives to monitor. The Journal of Finance 50 (4): 1113-1146.

Sharpe, S. A. 1991. Credit rationing, concessionary lending, and debt maturity. Journal of Banking \& Finance 15 (3): 581-604.

Skinner, D. J. 2011. Discussion of "accounting standards and debt covenants: Has the "balance sheet approach" led to a decline in the use of balance sheet covenants?". Journal of Accounting and Economics 52 (2): 203-208.

Smith, C. W., and J. B. Warner. 1979. On financial contracting: An analysis of bond covenants. Journal of Financial Economics 7 (2): 117-161. 
Stohs, M. H., and D. C. Mauer. 1996. The determinants of corporate debt maturity structure.

Journal of Business: 279-312.

Yen, A. C., D. E. Hirst, and P. E. Hopkins. 2007. A content analysis of the comprehensive income exposure draft comment letters. Research in Accounting Regulation 19: 53-79. 
Table 1

Summary statistics for the Dealscan sample

Panel A and B show the summary statistics and industry breakdown respectively. Panel C shows the correlation estimates among OCI based and conventional volatility and profitability. Panel D shows the average and median levels of firm-level correlation between OCI and market (CRSP value-weighted index) returns calculated over the past 5 years. Sample period is 2004-2011. Variable definitions are provided in the Appendix 2.

\begin{tabular}{|c|c|c|c|c|c|c|c|c|c|c|}
\hline Variable & $N$ & Mean & Std & Median & Min & $5 \%$ & $25 \%$ & $75 \%$ & $95 \%$ & Max \\
\hline \multicolumn{11}{|l|}{ Loan characteristics } \\
\hline LOAN_SPREAD & 4,791 & 201.978 & 136.221 & 175.000 & 17.500 & 37.500 & 100.000 & 275.000 & 450.000 & 950.000 \\
\hline LOG_LOAN_SPREAD & 4,791 & 5.063 & 0.754 & 5.165 & 2.862 & 3.624 & 4.605 & 5.617 & 6.109 & 6.856 \\
\hline FIN_COV & 4,791 & 2.040 & 1.022 & 2.000 & 0.000 & 0.000 & 1.000 & 3.000 & 4.000 & 6.000 \\
\hline SECURED_DUM & 4,791 & 0.652 & 0.476 & 1.000 & 0.000 & 0.000 & 0.000 & 1.000 & 1.000 & 1.000 \\
\hline MATURITY & 4,791 & 52.223 & 18.516 & 60.000 & 3.000 & 12.000 & 37.000 & 60.000 & 84.000 & 96.000 \\
\hline LOG_MATURITY & 4,791 & 3.850 & 0.543 & 4.094 & 1.099 & 2.485 & 3.611 & 4.094 & 4.431 & 4.564 \\
\hline LOAN_SIZE & 4,791 & 2.944 & 0.075 & 2.950 & 2.675 & 2.805 & 2.898 & 2.997 & 3.054 & 3.114 \\
\hline PERPRICE & 4,791 & 0.775 & 0.417 & 1.000 & 0.000 & 0.000 & 1.000 & 1.000 & 1.000 & 1.000 \\
\hline \multicolumn{11}{|l|}{ Firm characteristics } \\
\hline STD_CHG_AOCI/A & 4,791 & 0.012 & 0.015 & 0.006 & 0.000 & 0.000 & 0.001 & 0.016 & 0.042 & 0.120 \\
\hline$C H G \_A O C I / A$ & 4,791 & 0.000 & 0.017 & 0.000 & -0.114 & -0.028 & -0.002 & 0.004 & 0.024 & 0.092 \\
\hline$S T D \_R O A$ & 4,791 & 0.062 & 0.093 & 0.031 & 0.002 & 0.006 & 0.015 & 0.068 & 0.226 & 1.004 \\
\hline$R O A$ & 4,791 & 0.030 & 0.100 & 0.043 & -0.721 & -0.144 & 0.012 & 0.077 & 0.142 & 0.341 \\
\hline$M \_B$ & 4,791 & 1.725 & 0.844 & 1.480 & 0.620 & 0.937 & 1.183 & 2.007 & 3.371 & 7.047 \\
\hline$L E V$ & 4,791 & 0.165 & 0.152 & 0.132 & 0.000 & 0.000 & 0.041 & 0.244 & 0.484 & 0.706 \\
\hline TANGIBILITY & 4,791 & 0.309 & 0.245 & 0.230 & 0.007 & 0.034 & 0.108 & 0.468 & 0.803 & 0.937 \\
\hline LOG_SIZE & 4,791 & 0.750 & 1.585 & 0.728 & -3.575 & -1.867 & -0.372 & 1.849 & 3.374 & 5.154 \\
\hline ZSCORE & 4,791 & 1.484 & 1.404 & 1.561 & -6.781 & -0.659 & 0.712 & 2.340 & 3.508 & 5.600 \\
\hline \multicolumn{11}{|l|}{ Macro-economic variables } \\
\hline$B A A \_A A A \_S P R E A D$ & 4,791 & 1.072 & 0.450 & 0.920 & 0.620 & 0.660 & 0.870 & 1.160 & 1.680 & 3.380 \\
\hline TERM_SPREAD & 4,791 & 0.974 & 0.982 & 0.690 & -0.140 & -0.110 & 0.100 & 1.770 & 2.720 & 2.830 \\
\hline RECESSION & 4,791 & 0.155 & 0.362 & 0.000 & 0.000 & 0.000 & 0.000 & 0.000 & 1.000 & 1.000 \\
\hline
\end{tabular}


Panel B: Industry breakdown of the Dealscan sample

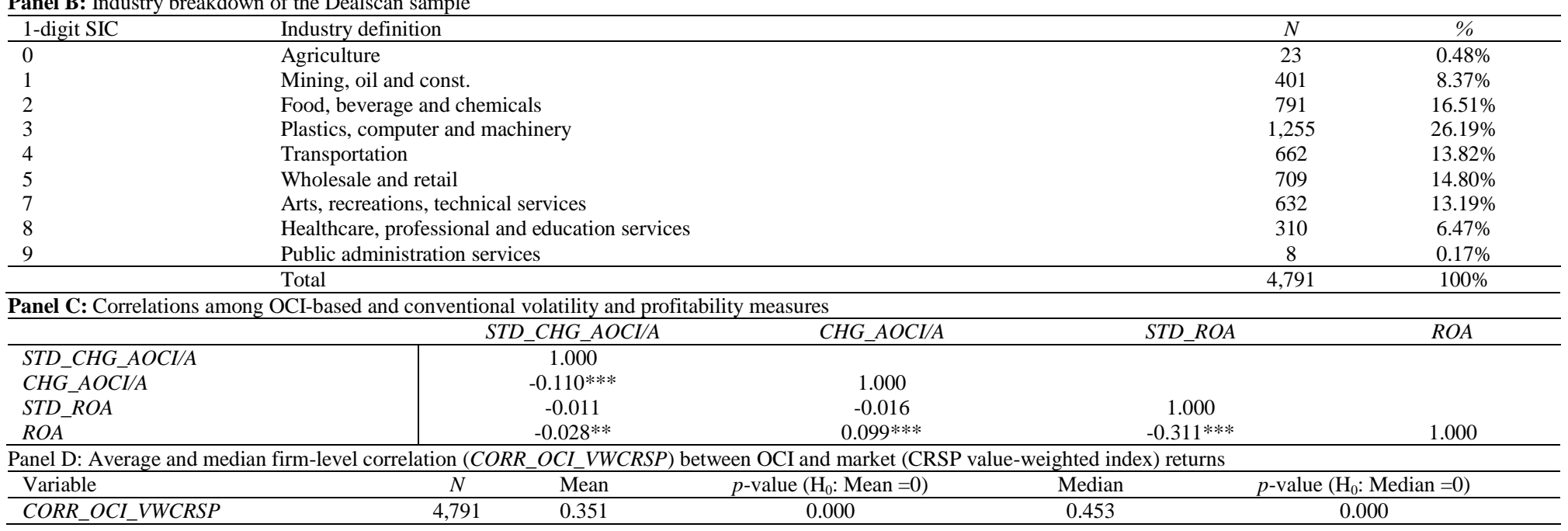


Table 2

Relation between cost of loan and OCI-based volatility

This table shows the estimation results for the regression of firm's cost of loan. The sample covers the 2004-2011 period. Variable definitions are provided in the Appendix 2. Heteroskedasticityrobust standard errors clustered at two- digit industry code level are used to determine statistical significance. $* * *, * *$ and $*$ denote significance at the $1 \%, 5 \%$ and $10 \%$ level, respectively.

\begin{tabular}{|c|c|c|c|c|c|c|c|c|}
\hline \multirow{3}{*}{ Independent variable } & \multirow{2}{*}{\multicolumn{2}{|c|}{ [1] }} & \multicolumn{4}{|c|}{ Dependent variable $=L O G_{-} L O A N \_S P R E A D$} & & \\
\hline & & & \multicolumn{2}{|c|}{$[2]$} & \multicolumn{2}{|c|}{$[3]$} & \multicolumn{2}{|l|}{ [4] } \\
\hline & Coefficient & $\begin{array}{c}p- \\
\text { value }\end{array}$ & Coefficient & $\begin{array}{c}p- \\
\text { value }\end{array}$ & Coefficient & $\begin{array}{c}p- \\
\text { value }\end{array}$ & Coefficient & $\begin{array}{c}p- \\
\text { value }\end{array}$ \\
\hline Intercept & $5.223 * * *$ & 0.000 & $10.253^{* * *}$ & 0.000 & $9.919 * * *$ & 0.000 & $9.905 * * *$ & 0.000 \\
\hline$S T D \_C H G \_A O C I / A$ & $3.454 * * *$ & 0.000 & $14.636 * * *$ & 0.000 & $4.824 * *$ & 0.011 & $3.962 * *$ & 0.031 \\
\hline \multicolumn{9}{|l|}{ Firm characteristics } \\
\hline CHG_AOCI/A & $-2.971 * * *$ & 0.000 & $-2.158 * * *$ & 0.000 & $-1.457 * *$ & 0.018 & $-0.949 *$ & 0.077 \\
\hline$S T D \_R O A$ & $0.963 * * *$ & 0.000 & $0.866 * * *$ & 0.008 & $0.414^{*}$ & 0.060 & $0.379 *$ & 0.079 \\
\hline $\mathrm{ROA}^{-}$ & $-0.626^{* * *}$ & 0.007 & $-0.658 * *$ & 0.047 & -0.247 & 0.379 & -0.277 & 0.341 \\
\hline$M \_B$ & $-0.078 * * *$ & 0.002 & $-0.352 * * *$ & 0.000 & $-0.127 * * *$ & 0.009 & $-0.108 * *$ & 0.024 \\
\hline$L E V$ & $0.894 * * *$ & 0.000 & $0.516^{* * * *}$ & 0.003 & 0.226 & 0.145 & 0.182 & 0.246 \\
\hline TANGIBILITY & -0.082 & 0.392 & 0.057 & 0.896 & -0.229 & 0.321 & -0.270 & 0.224 \\
\hline$L O G \_S I Z E$ & $-0.177 * * *$ & 0.000 & $0.136^{* *}$ & 0.047 & -0.080 & 0.183 & -0.071 & 0.193 \\
\hline ZSCORE & $-0.066^{* * *}$ & 0.000 & -0.023 & 0.685 & -0.033 & 0.438 & -0.027 & 0.529 \\
\hline \multicolumn{9}{|l|}{ Loan characteristics } \\
\hline$L O A N \_S I Z E$ & & & $-1.503 * * *$ & 0.000 & $-1.583^{* * *}$ & 0.000 & $-1.620 * * *$ & 0.000 \\
\hline PERPR $\bar{R} I C E$ & & & $-0.136^{* * *}$ & 0.004 & $-0.109 * *$ & 0.017 & $-0.110^{* *}$ & 0.015 \\
\hline \multicolumn{9}{|l|}{ Macroeconomic variables } \\
\hline BAA_AAA_SPREAD & & & & & $0.211 * * *$ & 0.000 & $0.324 * * *$ & 0.000 \\
\hline TERM_SPREAD & & & & & $0.292 * * *$ & 0.000 & $0.296 * * *$ & 0.000 \\
\hline RECESSION & & & & & & & $-0.200 * * *$ & 0.000 \\
\hline Loan Type Dummies & \multicolumn{2}{|l|}{ No } & \multicolumn{2}{|l|}{ Yes } & \multicolumn{2}{|c|}{ Yes } & \multicolumn{2}{|l|}{ Yes } \\
\hline Loan Purpose Dummies & \multicolumn{2}{|l|}{ No } & \multicolumn{2}{|l|}{ Yes } & \multicolumn{2}{|c|}{ Yes } & \multicolumn{2}{|l|}{ Yes } \\
\hline Firm Dummies & \multicolumn{2}{|l|}{ No } & \multicolumn{2}{|l|}{ Yes } & \multicolumn{2}{|c|}{ Yes } & \multicolumn{2}{|c|}{ Yes } \\
\hline$R^{2}$ & \multicolumn{2}{|l|}{0.313} & \multicolumn{2}{|l|}{0.688} & \multicolumn{2}{|c|}{0.800} & \multicolumn{2}{|c|}{0.803} \\
\hline$N$ & \multicolumn{2}{|l|}{4,791} & \multicolumn{2}{|l|}{4,791} & \multicolumn{2}{|c|}{4,791} & \multicolumn{2}{|c|}{4,791} \\
\hline
\end{tabular}


Table 3

Relation between other loan characteristics (non-price terms) and OCI-based volatility

This table shows the estimation results for covenant intensity, collateral presence and maturity specifications. The sample covers the 2004-2011 period. Variable definitions are provided in the Appendix 2. Heteroskedasticity-robust standard errors clustered at two- digit industry code level are used to determine statistical significance. $* * *, * *$ and * denote significance at the $1 \%, 5 \%$ and $10 \%$ level, respectively.

\begin{tabular}{|c|c|c|c|c|c|c|c|c|}
\hline \multirow{4}{*}{ Independent variable } & \multicolumn{8}{|c|}{ Dependent variables } \\
\hline & \multirow{2}{*}{\multicolumn{2}{|c|}{$\frac{F I N \_C O V}{[1]}$}} & \multirow{2}{*}{\multicolumn{2}{|c|}{ TOT_COV }} & \multicolumn{2}{|c|}{ SECURED_DUM } & \multicolumn{2}{|c|}{ LOG_MATURITY } \\
\hline & & & & & \multicolumn{2}{|c|}{$[3]$} & \multicolumn{2}{|c|}{$[4]$} \\
\hline & Coefficient & $\begin{array}{c}p- \\
\text { value }\end{array}$ & Coefficient & $\begin{array}{c}p- \\
\text { value }\end{array}$ & Coefficient & $\begin{array}{c}p- \\
\text { value }\end{array}$ & Coefficient & $\begin{array}{c}p- \\
\text { value }\end{array}$ \\
\hline Intercept & $4.253 * * *$ & 0.002 & $10.968 * * *$ & 0.002 & 21.813 & 0.179 & -0.699 & 0.314 \\
\hline$S T D \_C H G \_A O C I / A$ & 2.941 & 0.311 & -2.674 & 0.644 & $45.576^{*}$ & 0.065 & 0.569 & 0.385 \\
\hline \multicolumn{9}{|l|}{ Firm Characteristics } \\
\hline$C H G \_A O C I / A$ & 0.100 & 0.941 & 1.585 & 0.669 & -17.639 & 0.212 & 0.262 & 0.705 \\
\hline$S T D \_R O A$ & 0.011 & 0.976 & 1.170 & 0.353 & $11.045^{*}$ & 0.074 & 0.041 & 0.777 \\
\hline$R O A^{-}$ & -0.424 & 0.481 & 0.504 & 0.678 & 7.254 & 0.128 & 0.109 & 0.525 \\
\hline$M \_B$ & -0.007 & 0.931 & -0.190 & 0.232 & -0.140 & 0.805 & -0.015 & 0.585 \\
\hline$L E V$ & 0.313 & 0.508 & 0.654 & 0.536 & -1.341 & 0.785 & & \\
\hline TANGIBILITY & 0.097 & 0.862 & -1.119 & 0.381 & 0.663 & 0.869 & 0.110 & 0.723 \\
\hline$L O G \_S I Z E$ & -0.053 & 0.620 & $-0.369 *$ & 0.075 & $-2.490 * * *$ & 0.004 & 0.023 & 0.691 \\
\hline ZSCORE & 0.065 & 0.355 & -0.247 & 0.140 & $-2.675 * * *$ & 0.002 & 0.018 & 0.545 \\
\hline \multicolumn{9}{|l|}{ Loan Characteristics } \\
\hline$L O A N \_S I Z E$ & $-0.882 *$ & 0.046 & $-2.181 *$ & 0.052 & -8.113 & 0.120 & $1.535 * * *$ & 0.000 \\
\hline PERPRICE & $0.290 * * *$ & 0.000 & $0.444 * * *$ & 0.009 & 0.474 & 0.388 & 0.037 & 0.253 \\
\hline \multicolumn{9}{|l|}{ Macroeconomic Factors } \\
\hline BAA_AAA_SPREAD & -0.005 & 0.957 & 0.119 & 0.555 & $2.686^{* * *} *$ & 0.007 & $-0.111 * * *$ & 0.003 \\
\hline TERM_SPREAD & -0.039 & 0.102 & $-0.186^{* * *}$ & 0.005 & 0.346 & 0.118 & $-0.037 * * *$ & 0.002 \\
\hline RECESSION & 0.048 & 0.616 & 0.236 & 0.349 & -0.941 & 0.201 & -0.028 & 0.532 \\
\hline Loan Type Dummies & \multicolumn{2}{|l|}{ Yes } & \multicolumn{2}{|c|}{ Yes } & \multicolumn{2}{|c|}{ Yes } & \multicolumn{2}{|l|}{ Yes } \\
\hline Loan Purpose Dummies & \multicolumn{2}{|l|}{ Yes } & \multicolumn{2}{|c|}{ Yes } & \multicolumn{2}{|c|}{ Yes } & \multicolumn{2}{|l|}{ Yes } \\
\hline Firm Dummies & \multicolumn{2}{|l|}{ Yes } & \multicolumn{2}{|c|}{ Yes } & \multicolumn{2}{|c|}{ Yes } & \multicolumn{2}{|c|}{ Yes } \\
\hline$R^{2}$ & \multicolumn{2}{|l|}{0.663} & \multicolumn{2}{|c|}{0.755} & \multicolumn{2}{|c|}{0.456} & \multicolumn{2}{|c|}{0.647} \\
\hline$N$ & \multicolumn{2}{|l|}{4,791} & \multicolumn{2}{|c|}{4,791} & 828 & & 4,791 & \\
\hline
\end{tabular}




\section{Table 4}

\section{Summary statistics for the COMPUSTAT sample}

Panel A shows the summary statistics for the primary sample that has 21,034 firm-year observations based on 4,241 unique nonfinancial firm from 2004 to 2014. Panel B shows correlations among STD_CHG_AOCI/A, CHG_AOCI/A, STD_ROA and ROA.

Panel $C$ shows the mean and median correlation between OCI and market returns (CRSP value-weighted index) over the past five years. Panel D shows the volatility of change in AOCI components broken down by fiscal year. Component volatilities are calculated over the past five years for annual changes in unrealized derivative gains/losses (STD_CHG_DERI/A), pension/postretirement adjustments (STD_CHG_PEN/A), adjustments to marketable securities (STD_CHG_MSA/A), translation adjustments (STD_CHG_TRANS/A), and other adjustments not included in the previous components (STD_CHG_OTHER/A). Panel E shows the industry breakdown of the primary sample based on one digit SIC. Variable definitions are provided in the Appendix 2. All variables are trimmed at $0.5 \%$ and $99.5 \%$ of each variable's empirical distribution.

Panel A: Summary statistics for the primary sample

\begin{tabular}{|c|c|c|c|c|c|c|c|c|c|c|}
\hline Variable & $N$ & Mean & Std & Median & Min & $5 \%$ & $25 \%$ & $75 \%$ & $95 \%$ & $\operatorname{Max}$ \\
\hline ST3 & 20,905 & 0.442 & 0.372 & 0.338 & 0.000 & 0.000 & 0.098 & 0.844 & 1.000 & 1.000 \\
\hline ST5 & 20,905 & 0.620 & 0.361 & 0.667 & 0.000 & 0.001 & 0.314 & 1.000 & 1.000 & 1.000 \\
\hline STD_CHG_AOCI/A & 20,905 & 0.014 & 0.020 & 0.006 & 0.000 & 0.000 & 0.001 & 0.019 & 0.051 & 0.350 \\
\hline$C H G \_A O C I / A$ & 20,905 & -0.002 & 0.021 & 0.000 & -0.152 & -0.036 & 0.004 & 0.003 & 0.025 & 0.123 \\
\hline$S T D \_R O A$ & 20,905 & 0.102 & 0.605 & 0.039 & 0.002 & 0.006 & 0.018 & 0.093 & 0.309 & 40.007 \\
\hline$R O A$ & 20,905 & -0.021 & 0.277 & 0.035 & 12.034 & -0.399 & 0.017 & 0.072 & 0.146 & 0.555 \\
\hline$L E V$ & 20,905 & 0.250 & 0.190 & 0.224 & 0.000 & 0.004 & 0.101 & 0.358 & 0.610 & 0.998 \\
\hline ASSET_MAT & 20,905 & 11.939 & 18.373 & 7.064 & 0.126 & 0.868 & 3.116 & 15.511 & 34.376 & 468.164 \\
\hline$M \_B$ & 20,905 & 1.803 & 1.319 & 1.439 & 0.396 & 0.808 & 1.114 & 2.031 & 3.926 & 36.244 \\
\hline$A B N E A R N$ & 20,905 & 0.011 & 0.268 & 0.004 & -2.959 & -0.237 & 0.026 & 0.031 & 0.273 & 2.965 \\
\hline STD_RET & 20,905 & 10.856 & 6.253 & 9.225 & 2.725 & 4.141 & 6.537 & 13.337 & 23.199 & 48.920 \\
\hline$R A T I N G \_D U$ & 20,905 & 0.387 & 0.487 & 0.000 & 0.000 & 0.000 & 0.000 & 1.000 & 1.000 & 1.000 \\
\hline$R E G \_D \bar{U} M$ & 20,905 & 0.037 & 0.188 & 0.000 & 0.000 & 0.000 & 0.000 & 0.000 & 0.000 & 1.000 \\
\hline SIZE & 20,905 & 9.173 & 23.132 & 1.512 & 0.001 & 0.037 & 0.300 & 6.219 & 45.430 & 215.385 \\
\hline$L O G \_S I Z E$ & 20,905 & 0.318 & 2.146 & 0.414 & -6.989 & -3.309 & $1 . \overline{205}$ & 1.828 & 3.816 & 5.372 \\
\hline LOG_SIZE2 & & & 5643 & & 0.000 & 0.029 & 0.561 & 6.931 & 16.879 & 48.846 \\
\hline ITC_DUM & & 0.160 & 0.366 & 0.000 & 0.000 & 0.000 & 0.000 & 0.000 & 1.000 & 1.000 \\
\hline$L C \_D U M$ & 20,905 & 0.508 & 0.500 & 1.000 & 0.000 & 0.000 & 0.000 & 1.000 & 1.000 & 1.000 \\
\hline
\end{tabular}

Panel B: Correlations among conventional and OCI based profitability and volatility

\begin{tabular}{|c|c|c|c|c|}
\hline & STD_CHG_AOCI/A & CHG_AOCI/A & $S T D \_R O A$ & $R O A$ \\
\hline STD_CHG_AOCI/A & 1 & & & \\
\hline$C H G \_A O C I / A$ & $-0.146^{* * *}$ & 1 & & \\
\hline$S T D \_R O A$ & -0.000 & $0.016 * *$ & 1 & \\
\hline$R O A$ & $0.049 * * *$ & -0.005 & $-0.234 * * *$ & 1 \\
\hline
\end{tabular}


Panel C: Average and median firm-level correlation (CORR_OCI_VWCRSP) between OCI and market (CRSP valueweighted index) returns

\begin{tabular}{lccccc}
\hline Variable & $N$ & Mean & $p$-value $\left(\mathrm{H}_{0}\right.$ : Mean $\left.=0\right)$ & Median & $p$-value $\left(\mathrm{H}_{0}:\right.$ Median $\left.=0\right)$ \\
\hline CORR_OCI_VWCRSP & 20,905 & 0.289 & 0.000 & 0.338 & 0.000 \\
\hline
\end{tabular}

Panel D: Average volatility of OCI components broken down by fiscal year

\begin{tabular}{lcccccccccccc}
\hline Variable & 2004 & 2005 & 2006 & 2007 & 2008 & 2009 & 2010 & 2011 & 2012 & 2013 & 2014 \\
\hline STD_CHG_AOCI/A & 0.008 & 0.011 & 0.011 & 0.011 & 0.015 & 0.017 & 0.017 & 0.017 & 0.016 & 0.012 & 0.012 \\
Median OCI-component volatility & & & & & & & & & & \\
STD_CHG_DERI/A & 0.001 & 0.001 & 0.001 & 0.001 & 0.002 & 0.002 & 0.002 & 0.002 & 0.002 & 0.001 & 0.001 \\
STD_CHG_PEN/A & 0.003 & 0.003 & 0.004 & 0.003 & 0.005 & 0.005 & 0.006 & 0.006 & 0.005 & 0.005 & 0.006 \\
STD_CHG_MSA/A & 0.001 & 0.002 & 0.002 & 0.002 & 0.002 & 0.002 & 0.002 & 0.002 & 0.002 & 0.001 & 0.001 \\
STD_CHG_TRANS/A & 0.005 & 0.007 & 0.007 & 0.007 & 0.009 & 0.010 & 0.009 & 0.010 & 0.009 & 0.007 & 0.006 \\
STD_CHG_OTHER/A & 0.000 & 0.000 & 0.000 & 0.000 & 0.001 & 0.001 & 0.001 & 0.001 & 0.001 & 0.001 & 0.001 \\
\hline
\end{tabular}

Panel E: Industry breakdown of the primary sample

\begin{tabular}{clrr}
\hline 1-digit SIC & Industry definition & $N$ & $\%$ \\
\hline 0 & Agriculture & 83 & $0.40 \%$ \\
1 & Mining, oil and const. & 1,814 & $8.68 \%$ \\
2 & Food, beverage and chemicals & 4,141 & $19.81 \%$ \\
3 & Plastics, computer and machinery & 6,370 & $30.47 \%$ \\
4 & Transportation & 2,777 & $13.28 \%$ \\
5 & Wholesale and retail & 2,268 & $10.85 \%$ \\
7 & Arts, recreations, technical services & 2,496 & $11.94 \%$ \\
8 & Healthcare, professional and education services & 909 & $4.35 \%$ \\
9 & Public administration services & 47 & $0.22 \%$ \\
\hline & Total & 20,905 & $100 \%$ \\
\hline
\end{tabular}


Table 5

Relation between maturity/leverage and OCI-based volatility

Simultaneous equation estimates

This table shows the simultaneous equation results for two specifications that model the firm's use of debt and the maturity structure simultaneously. Panel A and B proxy maturity structure based on ST3 and ST5 respectively. Each system treats leverage $(L E V)$ and maturity structure $(S T 3, S T 5)$ endogenously. The sample covers the 2004-2014 period. Variable definitions are provided in the Appendix 2. ***, ** and * denote significance at the $1 \%, 5 \%$ and $10 \%$ level, respectively.

Panel A: Joint estimation results for ST3 and $L E V$

\begin{tabular}{|c|c|c|c|c|}
\hline \multirow{4}{*}{ Independent variable } & \multicolumn{4}{|c|}{ Dependent variable } \\
\hline & \multirow{2}{*}{\multicolumn{2}{|c|}{$\begin{array}{c}S T 3 \\
{[1]}\end{array}$}} & \multirow{2}{*}{\multicolumn{2}{|c|}{$\begin{array}{c}L E V \\
{[2]}\end{array}$}} \\
\hline & & & & \\
\hline & Coefficient & $p$-value & Coefficient & $p$-value \\
\hline Intercept & $0.466 * * *$ & 0.000 & $0.381 * * *$ & 0.000 \\
\hline STD_CHG_AOCI/A & $0.359 * * *$ & 0.002 & $-0.341 * * *$ & 0.000 \\
\hline CHG_AOCI/A & -0.118 & 0.299 & $-0.165^{* *}$ & 0.016 \\
\hline$S T D \_R O A$ & 0.002 & 0.631 & $-0.006 * *$ & 0.014 \\
\hline$R O A^{-}$ & $0.021 * *$ & 0.044 & $-0.066 * * *$ & 0.000 \\
\hline ST3 & & & $-0.408 * * *$ & 0.000 \\
\hline$L E V$ & $-0.237 * * *$ & 0.000 & & \\
\hline$A S S E T \_M A T$ & $-0.007 * * *$ & 0.000 & & \\
\hline$M \_B$ & $0.010 * * *$ & 0.000 & $-0.009 * * *$ & 0.000 \\
\hline$A \bar{B} N E A R N$ & $-0.035 * * *$ & 0.000 & -0.006 & 0.211 \\
\hline RATING_DUM & $-0.167 * * *$ & 0.000 & & \\
\hline$R E G \_D U M$ & $0.035^{* *}$ & 0.013 & $-0.042 * * *$ & 0.000 \\
\hline$L O G \_S I Z E$ & $-0.033 * * *$ & 0.000 & $0.010 * * *$ & 0.000 \\
\hline$L O G \_S I Z E 2$ & $0.009 * * *$ & 0.000 & & \\
\hline$I T C \_D U M$ & & & $-0.038 * * *$ & 0.000 \\
\hline$L C \_D U M$ & & & $0.011 * * *$ & 0.000 \\
\hline$S T D \_R E T$ & $0.005 * * *$ & 0.000 & $0.007 * * *$ & 0.000 \\
\hline Year dummies & \multicolumn{2}{|c|}{ Yes } & \multicolumn{2}{|c|}{ Yes } \\
\hline Industry dummies & \multicolumn{2}{|c|}{ Yes } & \multicolumn{2}{|c|}{ Yes } \\
\hline$R^{2}$ & \multicolumn{2}{|c|}{0.228} & \multicolumn{2}{|c|}{0.175} \\
\hline$N$ & \multicolumn{2}{|c|}{20,905} & \multicolumn{2}{|c|}{20,905} \\
\hline
\end{tabular}


Panel B: Joint estimation results for ST5 and $L E V$

\begin{tabular}{|c|c|c|c|c|}
\hline \multirow{4}{*}{ Independent variable } & \multicolumn{4}{|c|}{ Dependent variable } \\
\hline & \multirow{2}{*}{\multicolumn{2}{|c|}{$\begin{array}{l}\text { ST5 } \\
{[1]}\end{array}$}} & \multicolumn{2}{|c|}{$L E V$} \\
\hline & & & \multicolumn{2}{|c|}{ [2] } \\
\hline & Coefficient & $p$-value & Coefficient & $p$-value \\
\hline Intercept & $0.646 * * *$ & 0.000 & $0.510 * * *$ & 0.000 \\
\hline$S T D \_C H G \_A O C I / A$ & $0.286^{* *}$ & 0.020 & $-0.350 * * *$ & 0.000 \\
\hline$C H G_{-} A O C I / A$ & -0.164 & 0.159 & $-0.167 * *$ & 0.033 \\
\hline$S T D \_R O A$ & 0.002 & 0.615 & $-0.006 * *$ & 0.025 \\
\hline$R^{\prime} A^{-}$ & $0.026 * *$ & 0.012 & $-0.052 * * *$ & 0.000 \\
\hline ST5 & & & $-0.488 * * *$ & 0.000 \\
\hline$L E V$ & $-0.215 * * *$ & 0.000 & & \\
\hline$A S S E T \_M A T$ & $-0.001 * * *$ & 0.000 & & \\
\hline$M \_B$ & 0.001 & 0.608 & $-0.008 * * *$ & 0.000 \\
\hline$A \bar{B} N E A R N$ & $-0.020 * *$ & 0.025 & -0.009 & 0.148 \\
\hline RATING_DUM & $-0.160 * * *$ & 0.000 & & \\
\hline$R E G \_D U M$ & $-0.056 * * *$ & 0.000 & $-0.047 * * *$ & 0.000 \\
\hline$L O G \_S I Z E$ & $-0.019 * * *$ & 0.000 & $0.008 * * *$ & 0.000 \\
\hline$L O G \_S I Z E 2$ & $0.002 * * *$ & 0.000 & & \\
\hline$I T C_{-} \bar{D} U M$ & & & $-0.036 * * *$ & 0.000 \\
\hline$L C \_D U M$ & & & $0.018 * * *$ & 0.000 \\
\hline$S T \bar{D} \_R E T$ & $0.004 * * *$ & 0.000 & $0.006^{* * *}$ & 0.000 \\
\hline Year dummies & & & & \\
\hline Industry dummies & & & & \\
\hline$R^{2}$ & & & & \\
\hline$N$ & & & & \\
\hline
\end{tabular}


Table 6

Summary statistics for credit rating sample

Panel A shows the mapping of long-term S\&P credit ratings on RATINGSP. Panel B shows the summary statistics for the credit rating sample that has 9,681 firm-year observations based on 1,568 unique nonfinancial firm. The sample covers the $2004-2014$ period.

Panel A: Mapping of credit ratings onto RATINGSP

\begin{tabular}{lcccc}
\hline & Investment grade & & \multicolumn{2}{c}{ Speculative grade } \\
\cline { 2 - 3 } S\&P rating & RATINGSP & & S\&P rating & RATINGSP \\
AAA & 22 & BB+ & 12 \\
AA+ & 21 & BB & 11 \\
AA & 20 & BB- & 10 \\
AA- & 19 & B+ & 9 \\
A+ & 18 & B & 8 \\
A & 17 & B- & 6 \\
A- & 16 & CCC+ & 5 \\
BBB+ & 15 & CCC & 4 \\
BBB & 14 & CCC- & 3 \\
BBB- & 13 & CC & 2 \\
& & C & 1 \\
\hline
\end{tabular}

\begin{tabular}{|c|c|c|c|c|c|c|c|c|c|c|}
\hline Variable & $N$ & Mean & Median & Std & Min & $5 \%$ & $25 \%$ & $75 \%$ & $95 \%$ & Max \\
\hline RATINGSP & 9,681 & 12.388 & 12.000 & 3.273 & 1.000 & 8.000 & 10.000 & 15.000 & 18.000 & 22.000 \\
\hline LEAD RATINGSP & 9,681 & 12.332 & 12.000 & 3.331 & 1.000 & 7.000 & 10.000 & 15.000 & 18.000 & 22.000 \\
\hline$S T D \_C H G \_A O C I / A$ & 9,681 & 0.017 & 0.010 & 0.021 & 0.000 & 0.000 & 0.003 & 0.023 & 0.055 & 0.314 \\
\hline CHG_AOCI/A & 9,681 & -0.002 & 0.000 & 0.023 & -0.151 & ${ }_{0}^{-}$ & -0.006 & 0.004 & 0.028 & 0.121 \\
\hline$S T D \_R O A$ & 9,681 & 0.046 & 0.026 & 0.066 & 0.002 & 0.005 & 0.014 & 0.052 & 0.155 & 1.206 \\
\hline$R O A$ & 9,681 & 0.036 & 0.042 & 0.090 & -2.283 & $0 . \overline{-}$ & 0.014 & 0.075 & 0.139 & 0.393 \\
\hline INTCOV & 9,681 & 18.406 & 7.697 & 76.071 & 142938 & 2.332 & 4.758 & 14.245 & 47.306 & 2939.720 \\
\hline$L E V$ & 9,681 & 0.216 & 0.190 & 0.145 & 0.000 & 0.027 & 0.106 & 0.294 & 0.508 & 0.704 \\
\hline$L O G \_S I Z E$ & 9,681 & 1.973 & 1.885 & 1.420 & -1.898 & $0 \overline{305}$ & 0.932 & 2.974 & 4.450 & 5.372 \\
\hline$S T D \_R E T$ & 9,681 & 8.275 & 7.045 & 4.696 & 2.725 & 3.560 & 5.124 & 9.893 & 17.400 & 46.499 \\
\hline
\end{tabular}




\section{Table 7}

Relation between credit ratings and OCI-based volatility

This table shows the ordered-logit regression results for credit ratings. Dependent variable is $12-$ month ahead S\&P credit ratings (LEAD12_RATINGSP). Credit ratings are mapped as a number ranging between 22 (AAA) and 1 (D). The sample covers the 2004-2014 period. Variable definitions are provided in the Appendix 2. Heteroskedasticity-robust standard errors clustered at firm level are used to determine statistical significance. $* * *, * *$ and $*$ denote significance at the $1 \%, 5 \%$ and $10 \%$ level, respectively.

\begin{tabular}{|c|c|c|}
\hline \multirow{2}{*}{ Independent variable } & \multicolumn{2}{|c|}{ Dependent variable: $L E A D \_R A T I N G S P$} \\
\hline & Coefficient & $p$-value \\
\hline$S T D \_C H G \_A O C I / A$ & $-2.364 * *$ & 0.017 \\
\hline$C H \bar{G} \_A O C I / A$ & $2.744 * * *$ & 0.001 \\
\hline$S T D \_R O A$ & 0.165 & 0.631 \\
\hline$R O A$ & $3.366^{* * *}$ & 0.000 \\
\hline INTCOV & 0.000 & 0.952 \\
\hline RATINGSP & $2.795 * * *$ & 0.000 \\
\hline$L E V$ & $-3.312 * * *$ & 0.000 \\
\hline$L O G \_S I Z E$ & $0.241 * * *$ & 0.000 \\
\hline$S T D \_R E T$ & $-0.016^{*}$ & 0.091 \\
\hline Year dummies & \multicolumn{2}{|c|}{ Yes } \\
\hline Industry dummies & \multicolumn{2}{|c|}{ Yes } \\
\hline Pseudo $R^{2}$ & \multirow{2}{*}{\multicolumn{2}{|c|}{$\begin{array}{l}0.603 \\
9.681\end{array}$}} \\
\hline$N$ & & \\
\hline
\end{tabular}

